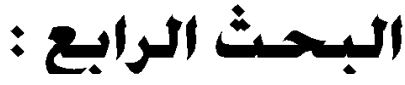

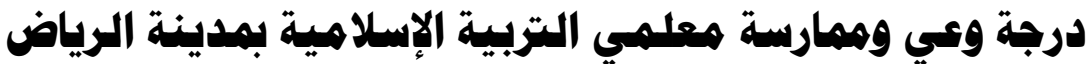
لاسترآتيجيات التقويه التواقعي هن وجهة الإينة نظر المشرفين يمدينة

\section{: إلفإ}

د. عبد الرحمن بن حمد الجابر

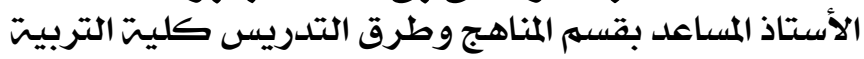
جامعت الإمام محمد بن سعود الإسلاميت بالمملكت العربيت السعوديت التريت 



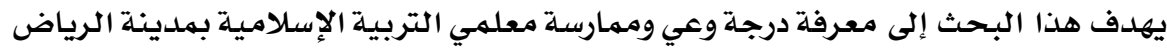

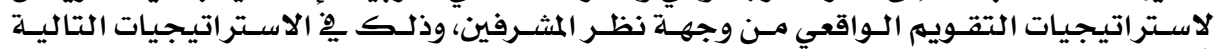

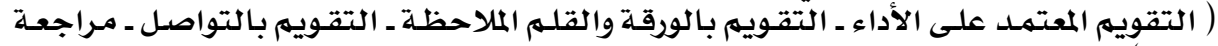

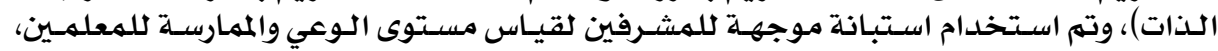

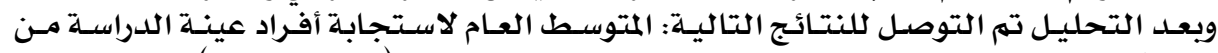

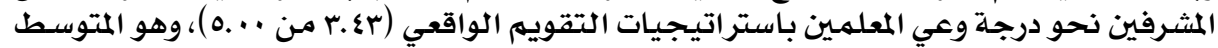

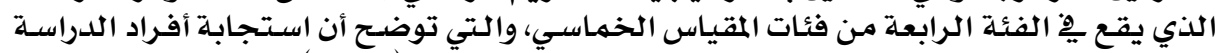

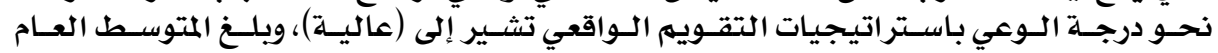

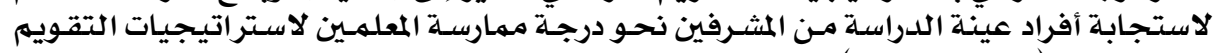

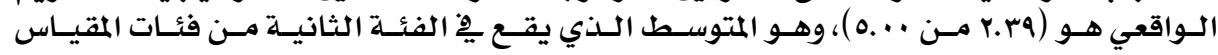

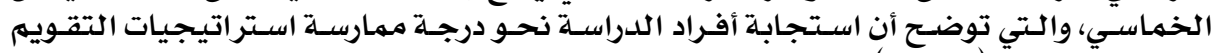
الواقعي تشير إلى الثي (متدنية توفية). الكلمات المفاحية : معلمي إلتية التربية الإسلامية -استراتيجيات التقويم الواقعي

The Degree of Awareness and Practice of Islamic Education Teachers in Riyadh City of Realistic Evaluation Strategies from the Supervisors' Point of View

DR.Abdulrahman Hamad ALjaber

\section{Abstract:}

This research aims to determine the degree of awareness and practice of Islamic education teachers in Riyadh city of realistic evaluation strategies from the supervisors' point of view, in the following strategies: (performancebased evaluation - paper-and-pencil evaluation (observation) communication evaluation - self-review). A supervisor-oriented questionnaire was used to measure the level of awareness and practice of teachers, and after the analysis the following results were obtained: The overall average response of the study sample of supervisors to teachers' awareness of realistic evaluation strategies (3.43 out of 5.00) this is the average which falls within the fourth category of the Likert scale, which shows that the response of study members towards awareness of realistic evaluation strategies indicates (high), and the overall average response of the study sample of supervisors to the degree that teachers practice realistic evaluation strategies was (2.39 out of 5.00) which is the average of the second category of the Likert scale, that shows the response of study members to the degree of practicing realistic evaluation strategies indicates (low).

Key words : Islamic Education Teachers - Realistic Evaluation Strategies 


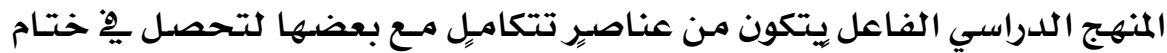

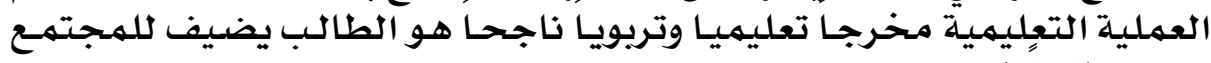
ويصنـع فارقا فيـه.

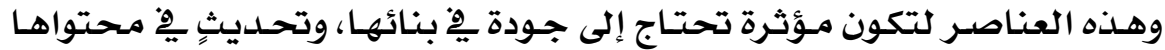

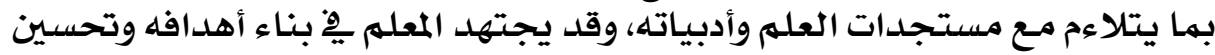

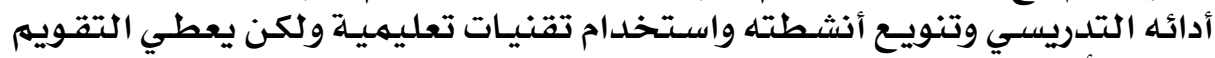

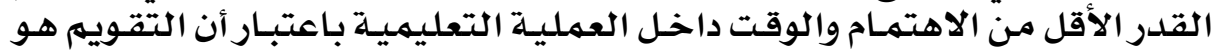
ختامس فقط.

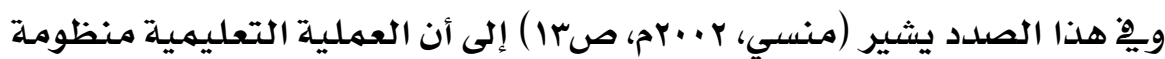

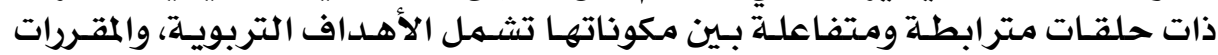

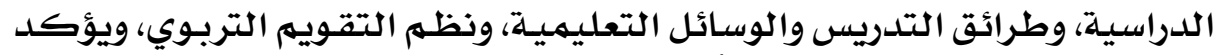

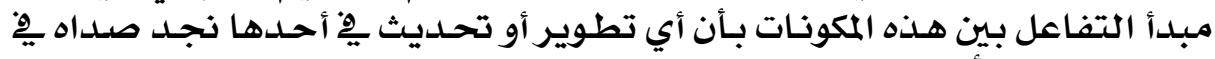

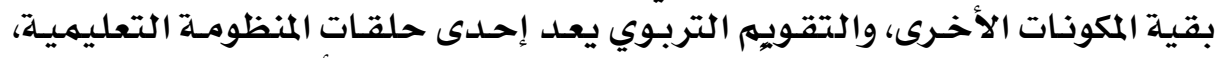

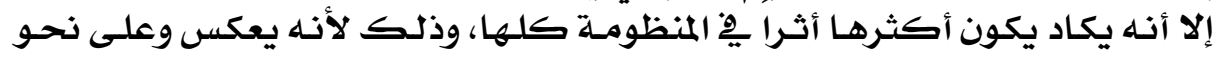

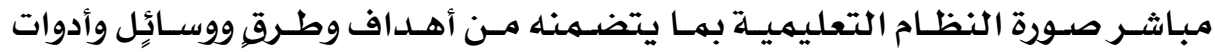

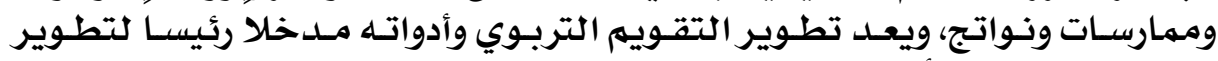

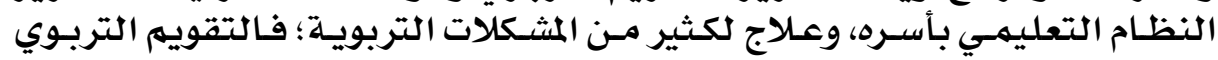

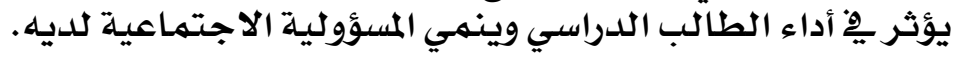

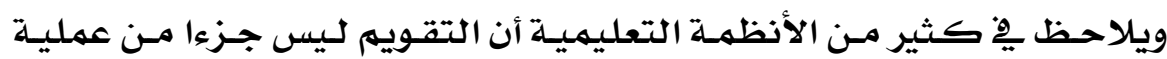

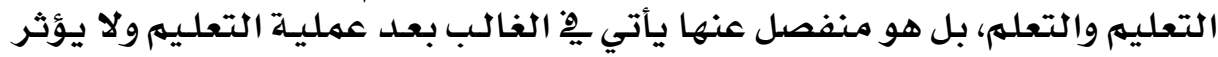

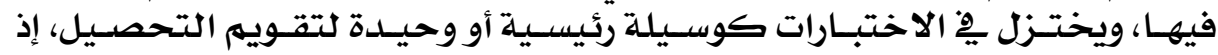

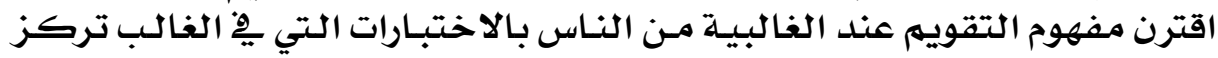

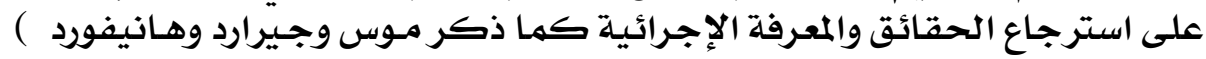

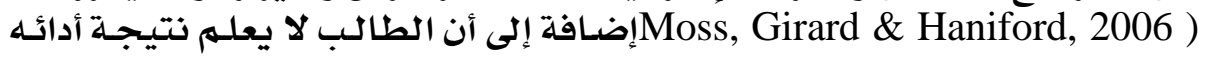

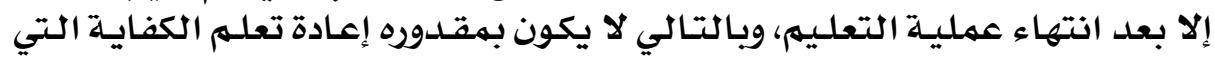

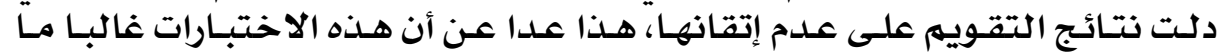

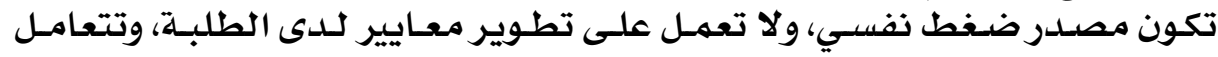

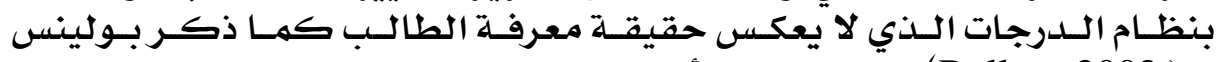

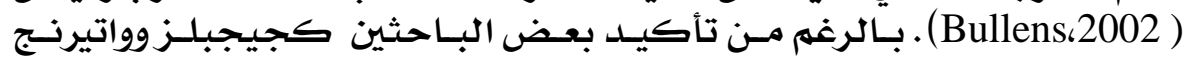

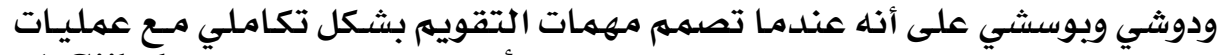

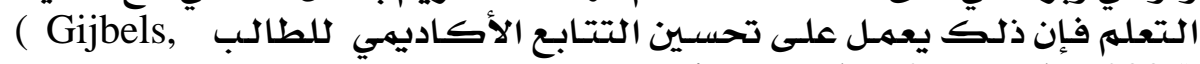
Watering, Dochy, \& Bossche, 2005)

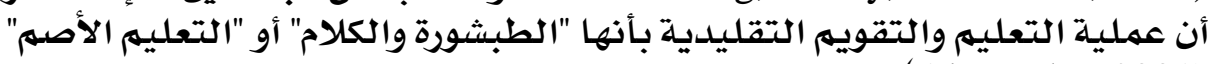

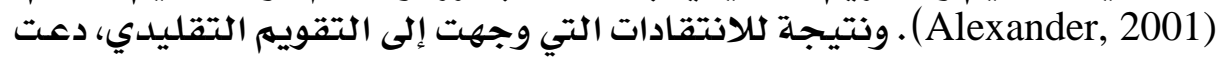

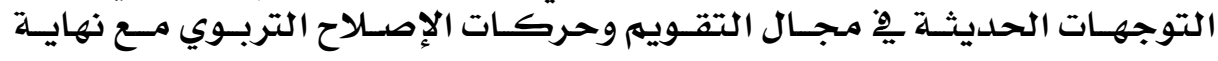




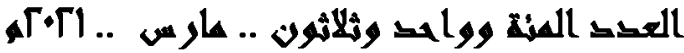

الثمانينات إلى نوع من التقويهم يعرف بـالتقويه البـديل Alternative Evaluation

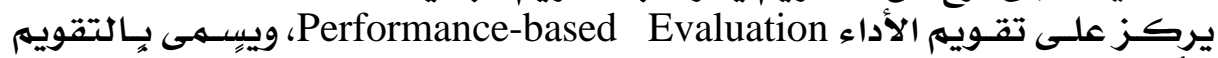

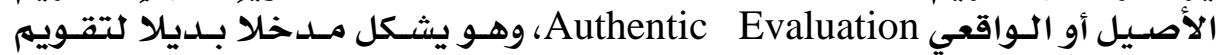

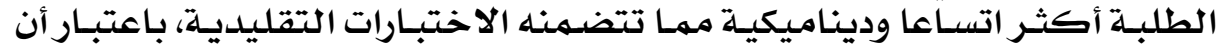

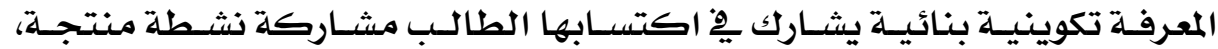

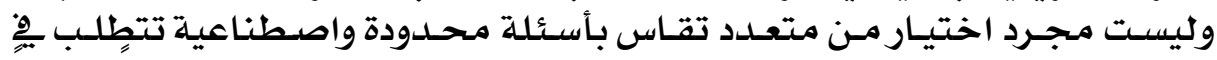

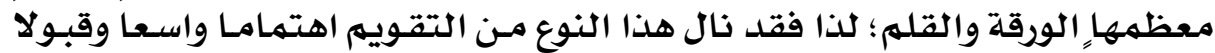

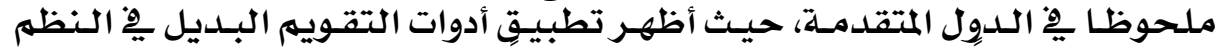

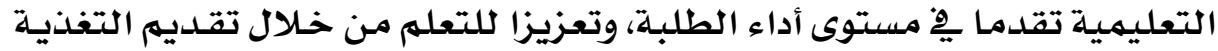

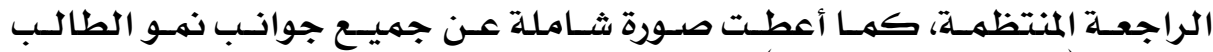

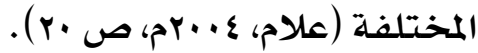

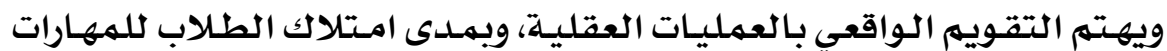

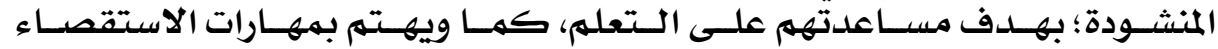

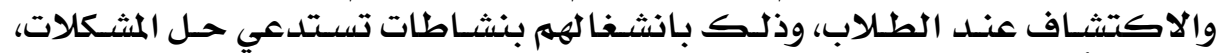

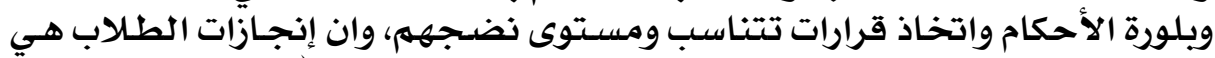

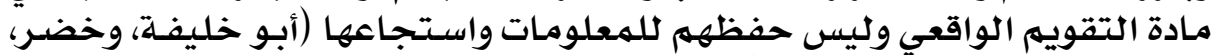

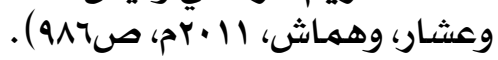

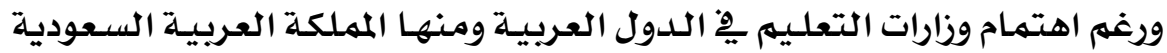

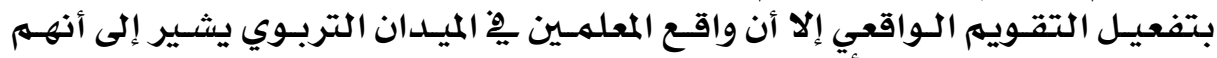

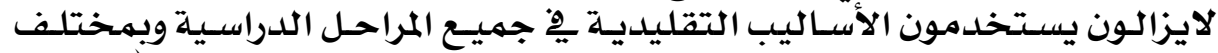

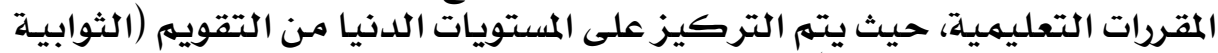

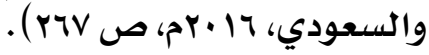

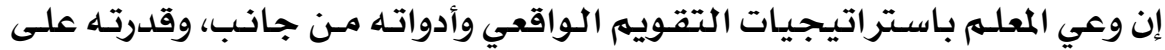

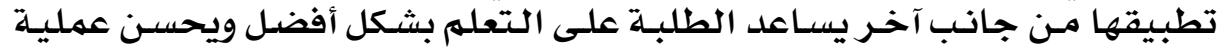

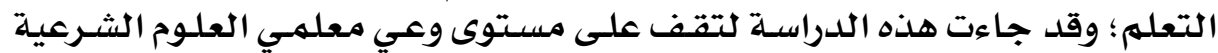

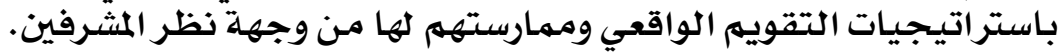

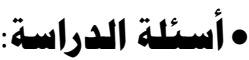

ِِِ ضوء ما سبق يهكن صياغة مشكلة الدراسلة يِّ السؤال الرئيس التالي:

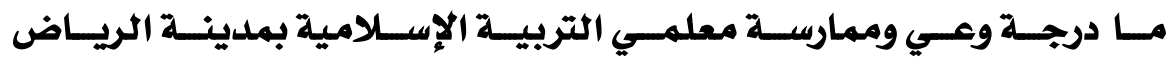

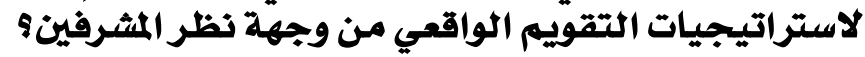

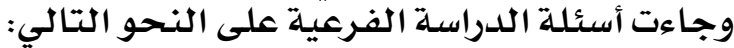

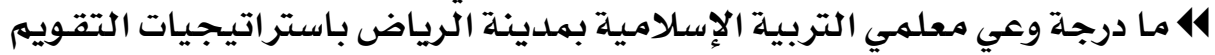

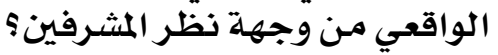

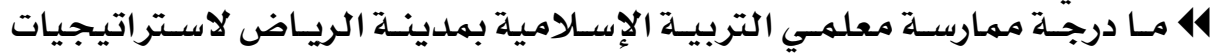

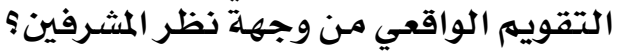

\section{$1 \& 9$}




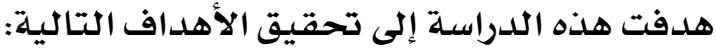

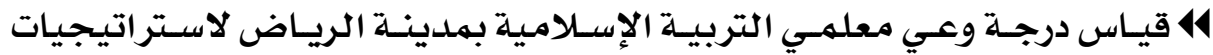

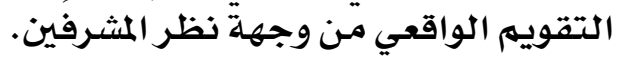

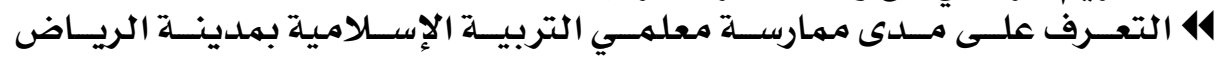

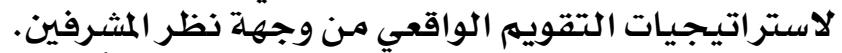

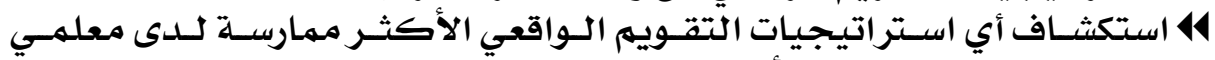

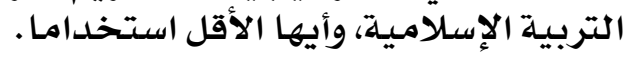

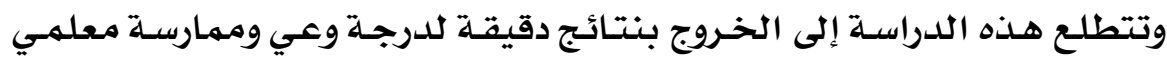

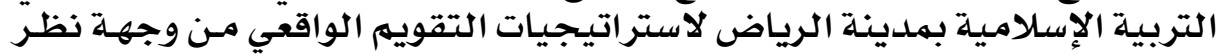

\section{المشرفين.

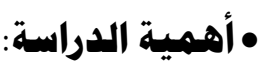

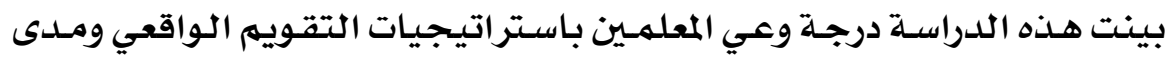

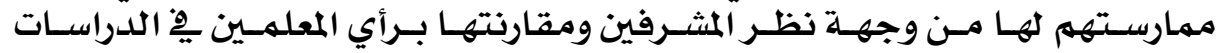

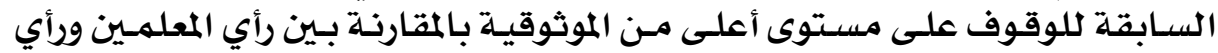

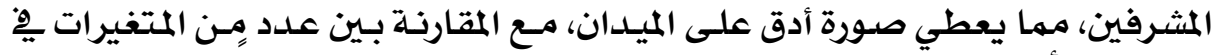

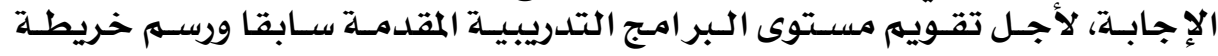

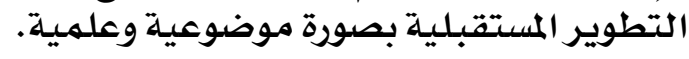

\section{• حدود الدراسة:}

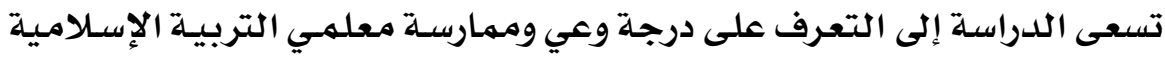

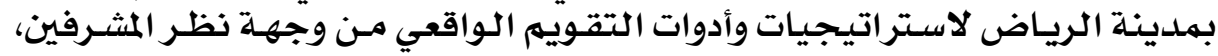

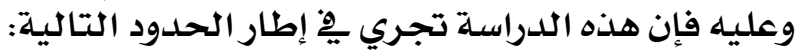

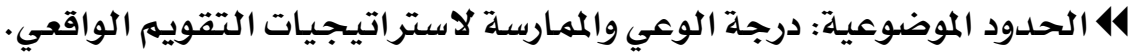

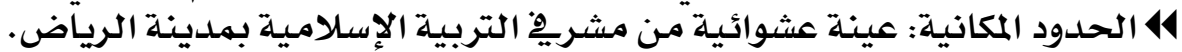

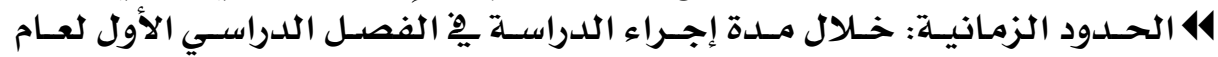

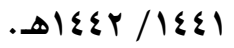

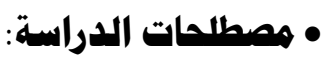

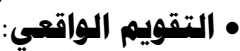

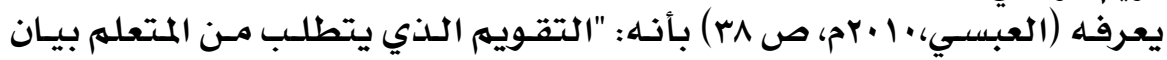

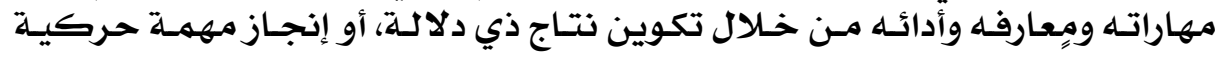

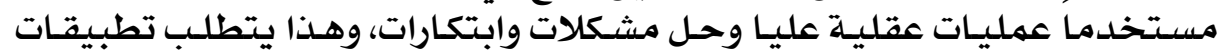

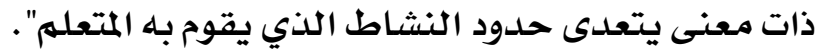

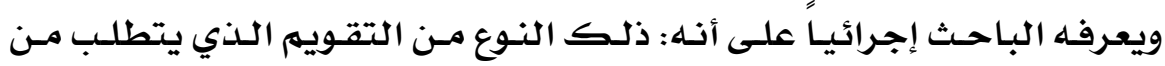

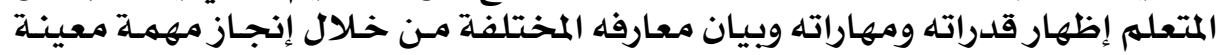

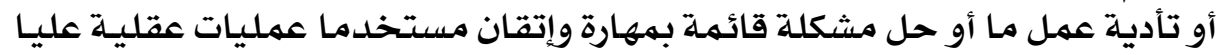




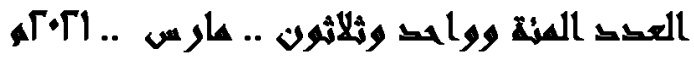

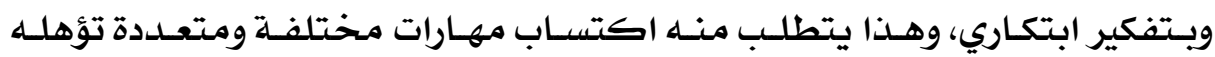

للقيام بذلكيك.

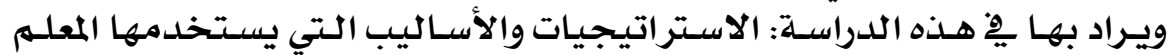

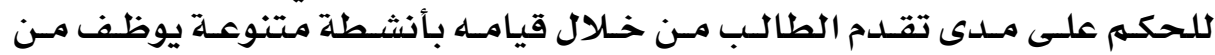

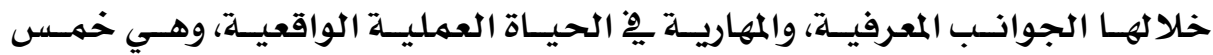

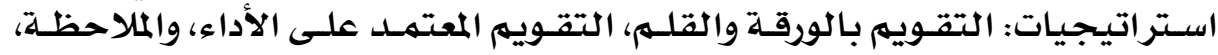

ومـراجعة الذات، والتواصلئ.

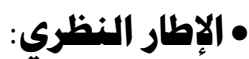

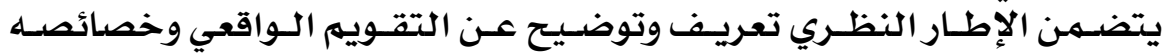

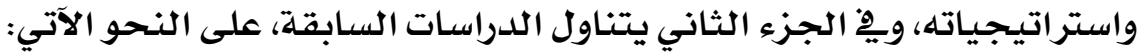

• هفهوم التقويم الواقعي:

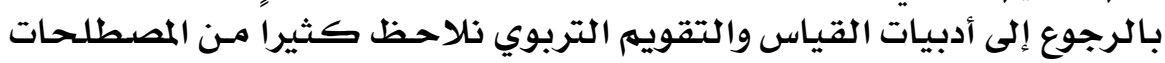

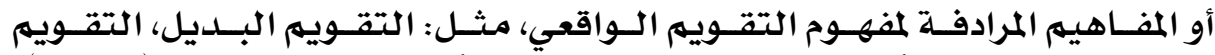

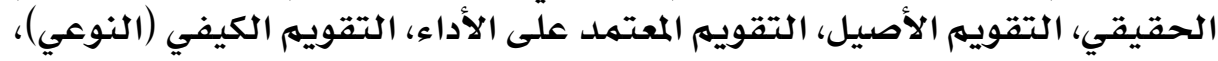

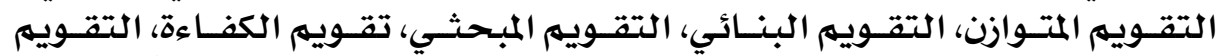

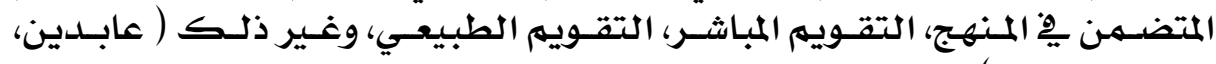

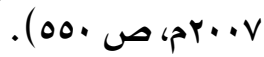

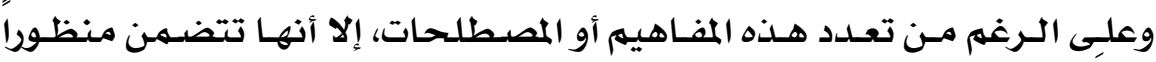

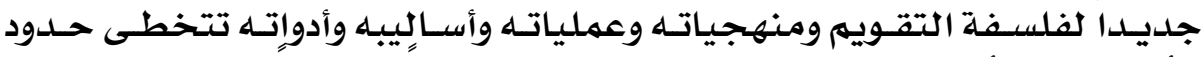

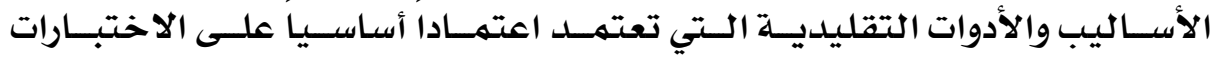

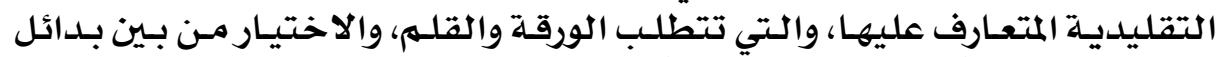

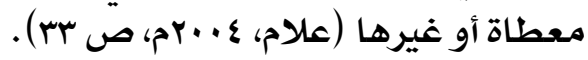

تتعلدد التعريفات التي تنـاولت مفهوم التقويهم الواقعي، ومـن التعريفات الواردة:

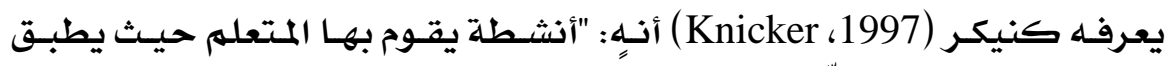
فيها معارفه ومهاراته، ويبيّن ذلك عمليا يِّة مواقف حياتية واقعيـة".

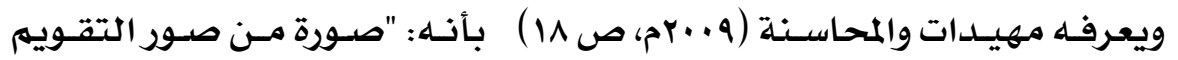

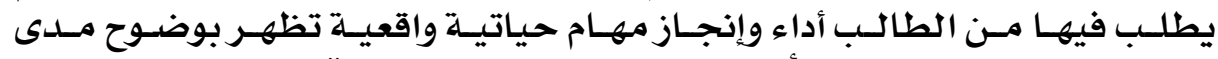

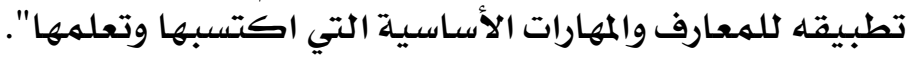
• التمولات الناجمة عن المنظور الجديد لاتقويم التربوي:

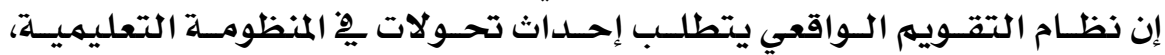

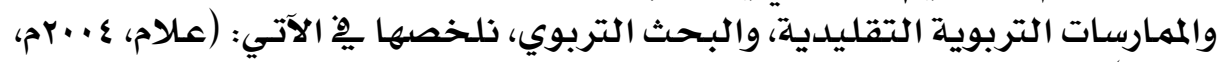




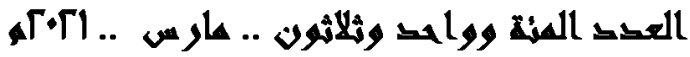

جدول (1): التحولات الناجمت عن المنظور الجديل للتقويم التربوي

\begin{tabular}{|c|c|}
\hline \multicolumn{2}{|c|}{ التحول } \\
\hline إلى & \\
\hline النظريت البنائيت والعمليات المعرفيت النمائيت & الاستناد إلى مبادئ النظريت السلوكيت هِ التعلهم \\
\hline 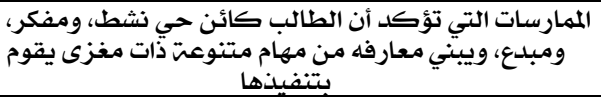 & الممارسات الصفيت التي تشجـع الدور السلبي للطالب \\
\hline ميسر، ومحكم، وموجه، وناصح مخلص & دور المعله كناقل للمعرفت، وسلطت ضاغطت \\
\hline 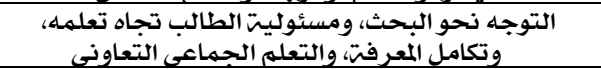 & المناهج التقليديتة، وحمليئق التفليم الثابتت لمواد دراسيتة \\
\hline إنجاز مهام أصيلتت تقيس التعلم المتعمقق & الاختبارات التقليديت التي تقيس التعلم السطحى \\
\hline 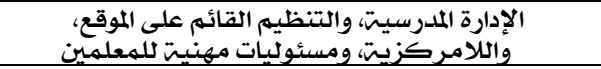 & التنظيم المدرسي الجامد، والمركزيت الصارمتة \\
\hline البحث التربوي الموجه نحو الفهم الكيفي لظاهرة معقدة & البحث التربوي الكمي الصـارم لعوامل منفصلت \\
\hline 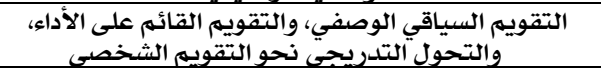 & الاختبارات المقنتنة، والامتحانات التقليديت \\
\hline
\end{tabular}

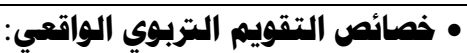

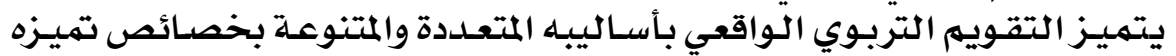

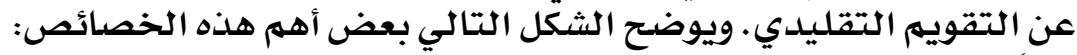

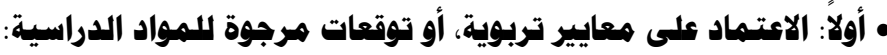

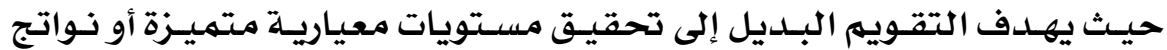

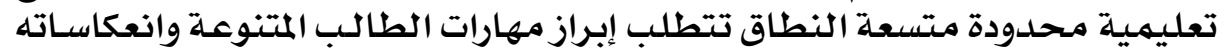

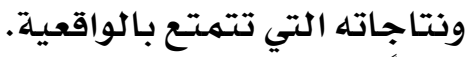

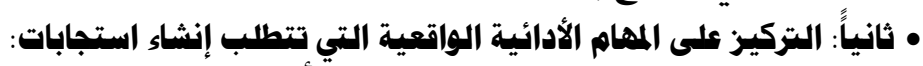

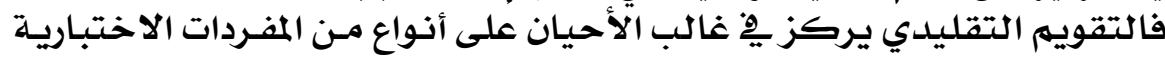

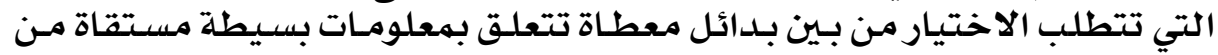

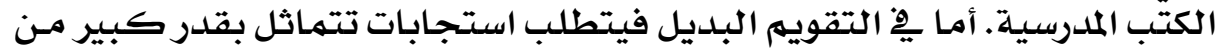

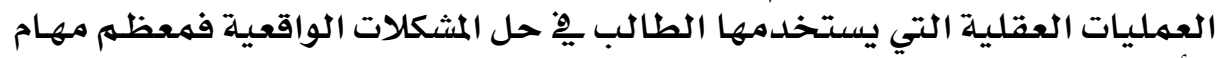

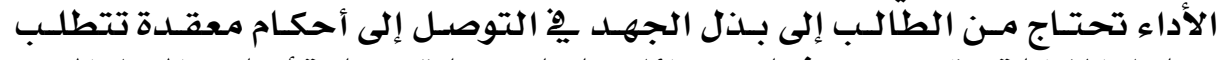

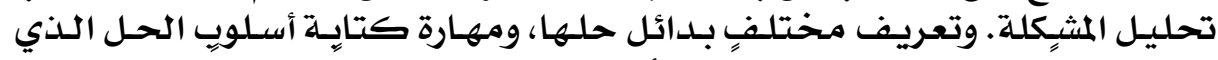

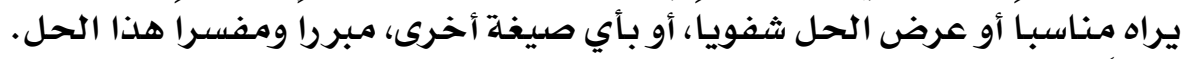

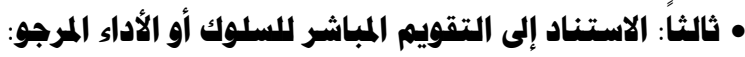

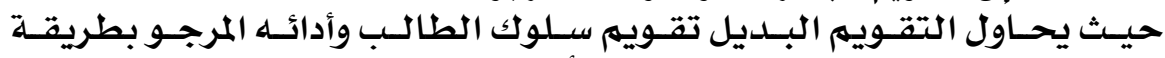

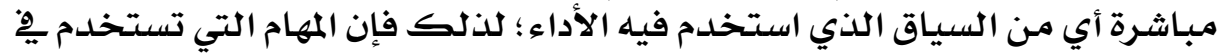

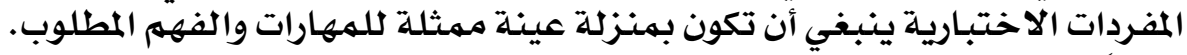

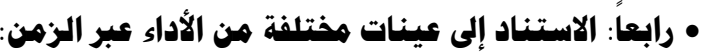

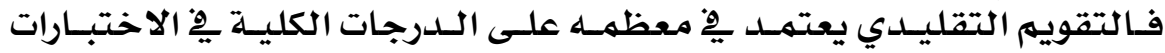

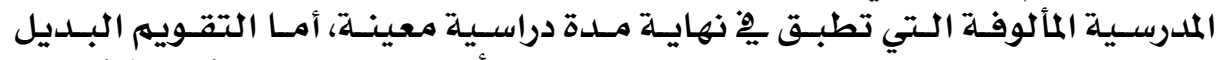

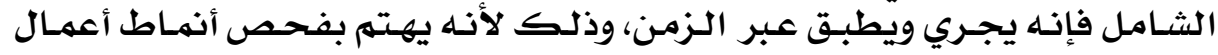

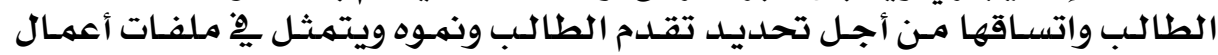

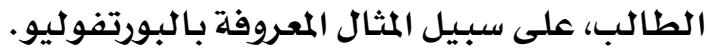




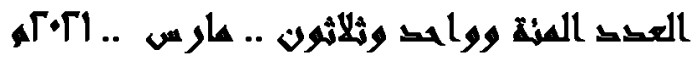

• خامسا: الاستناد إلى نظام التقويم القائم على المستويات المعيارية:

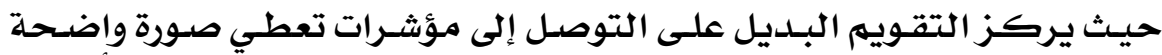

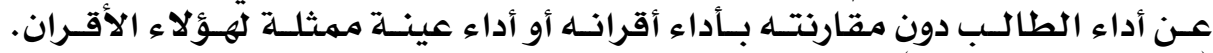

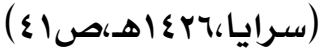

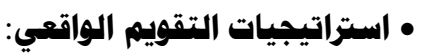

أورد كثير من البـاحثين تعريفات لاستراتيجيات التقويم الواقعي على النحو

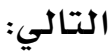

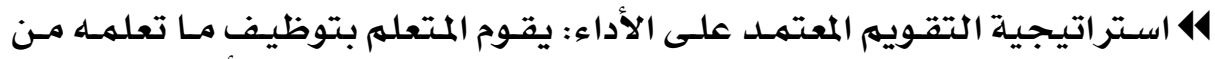

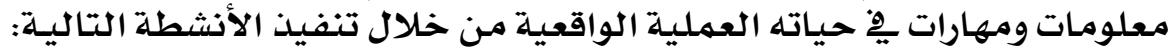
والعرض التوضيحي، ولعب الأدوار، والمحاكاكاة، والمناقشية.

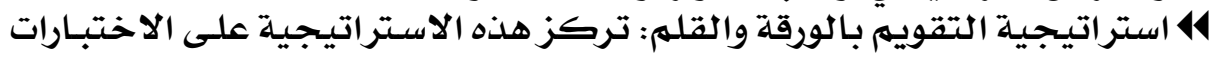
بأشكا لها المتعددة للتعرف على مستوى تحصيل الطلاب من المعلومات التهات التي سبق التقات دراستها.

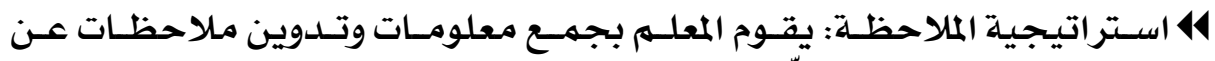

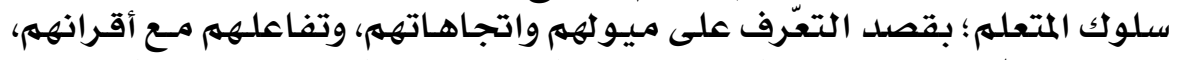

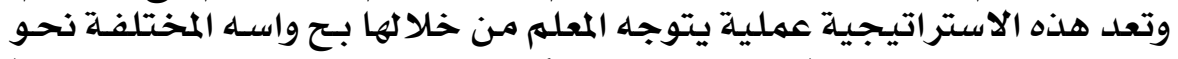

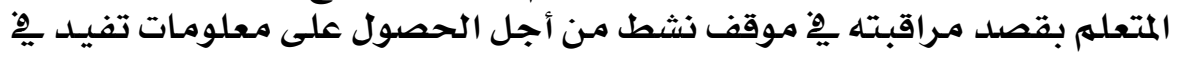

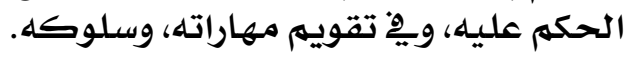

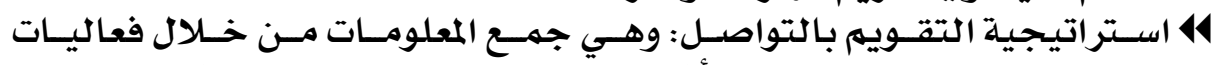

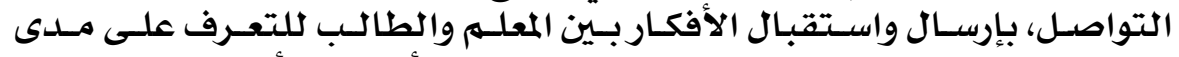

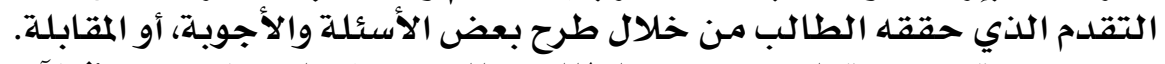

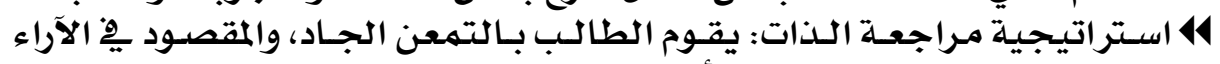

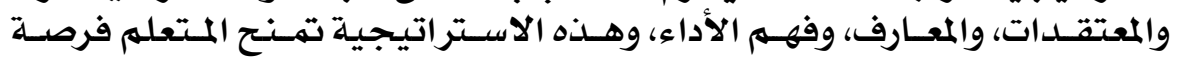

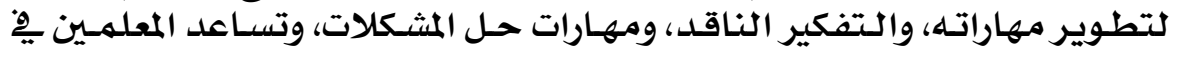

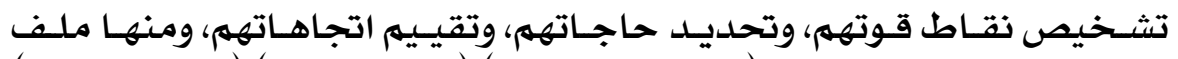

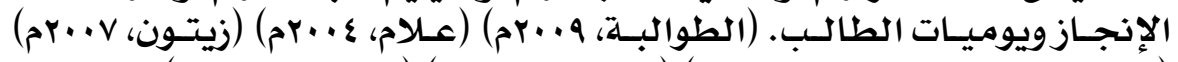

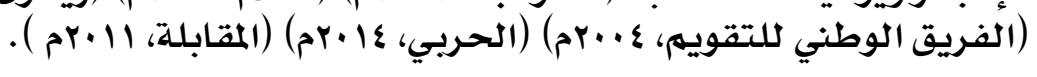

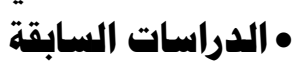

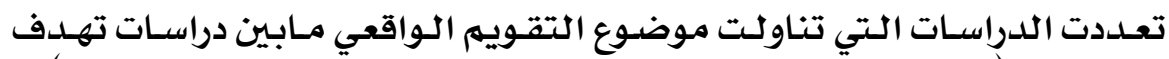

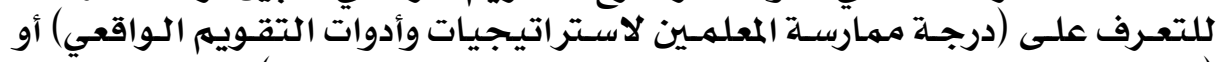

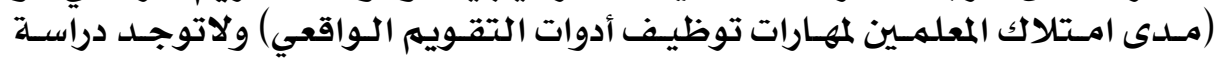

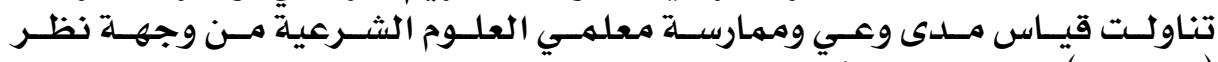

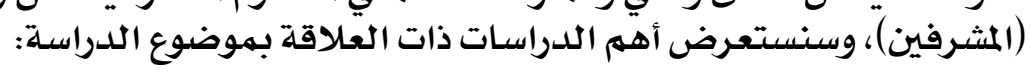

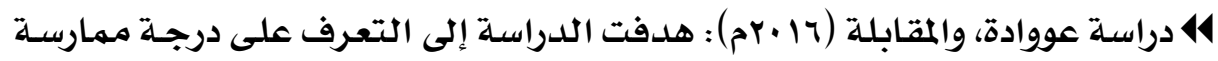

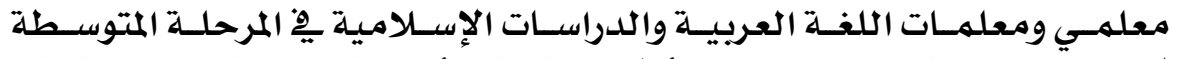

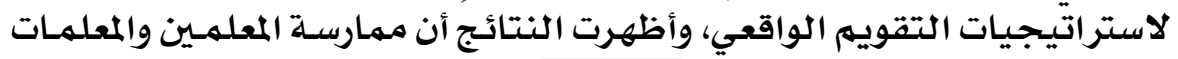

\section{$10 \%$}




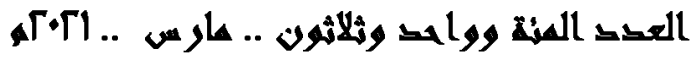

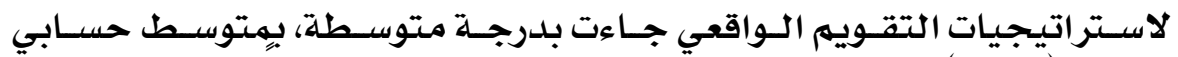

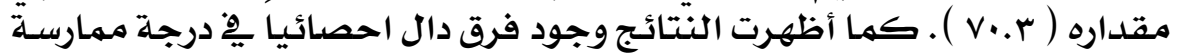

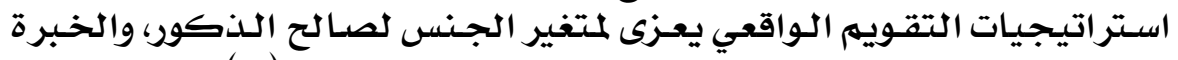

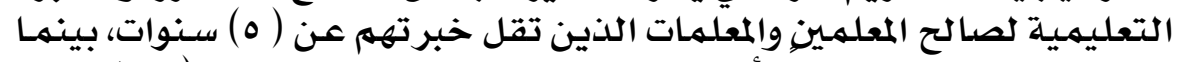

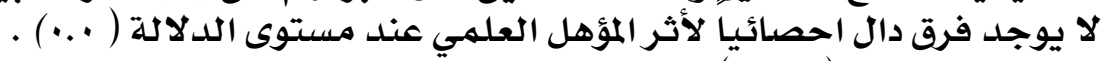

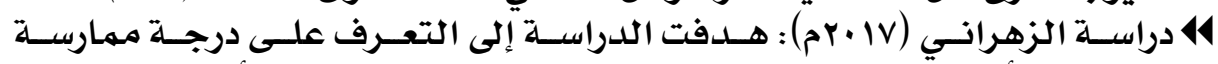

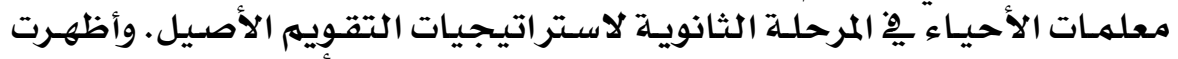

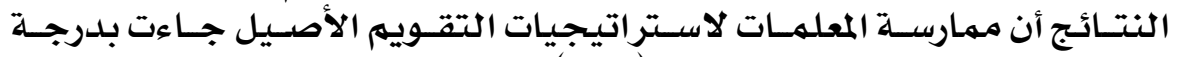

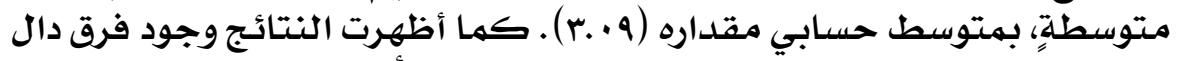

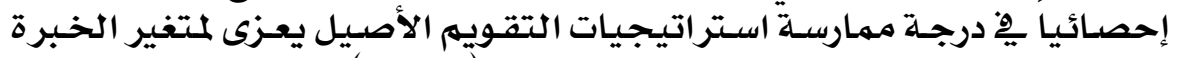

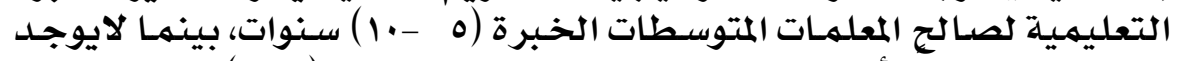

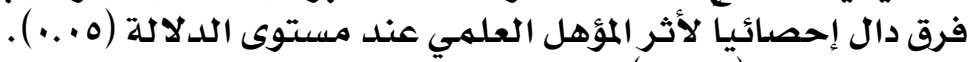

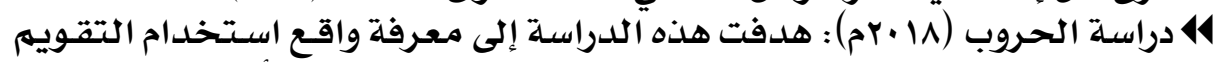

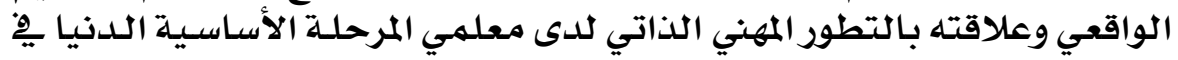

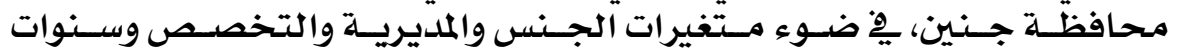

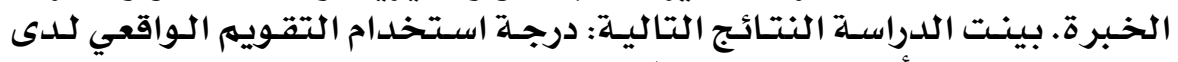

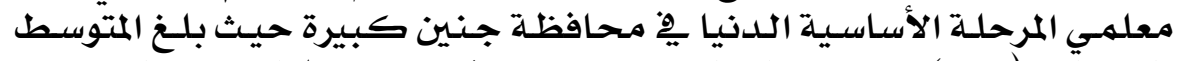

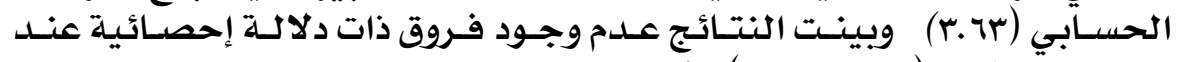

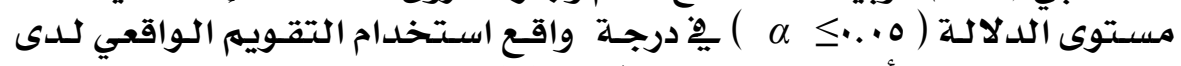

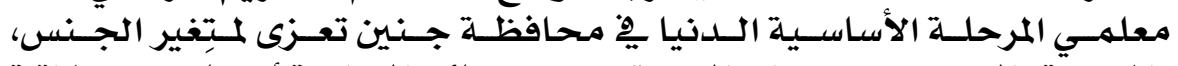

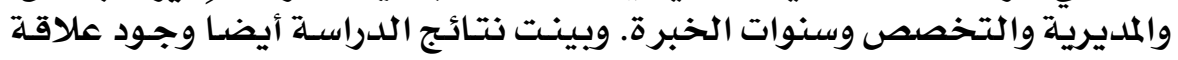

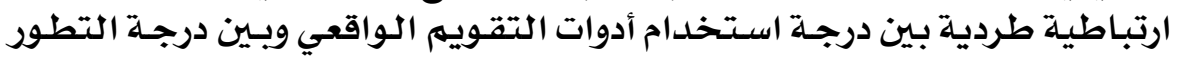

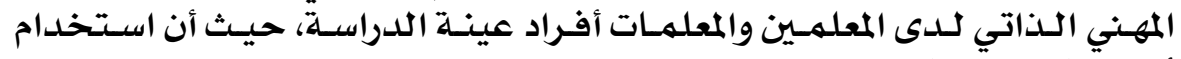

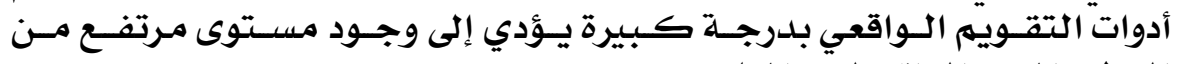

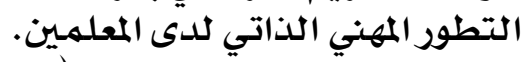

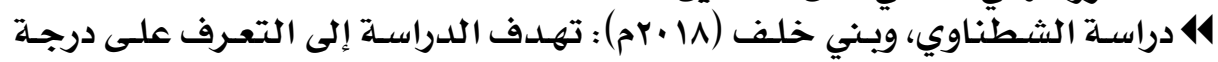

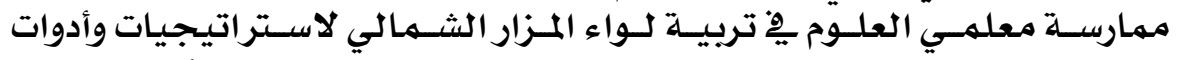

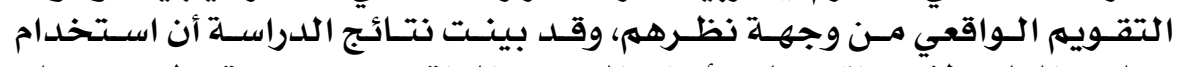

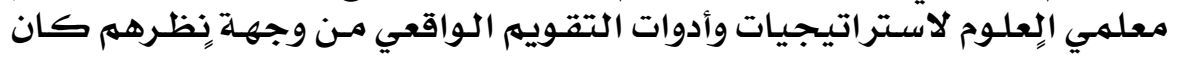

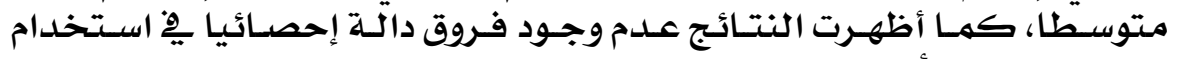

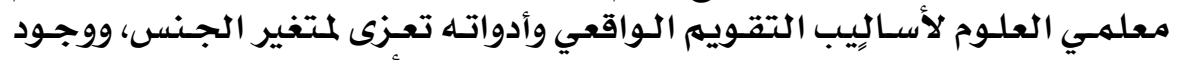

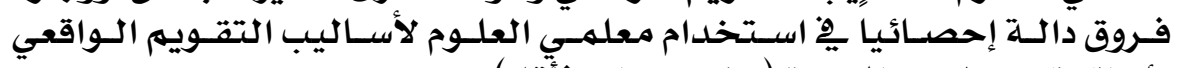

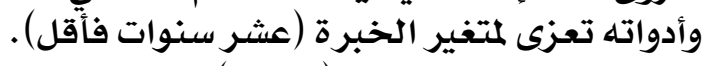

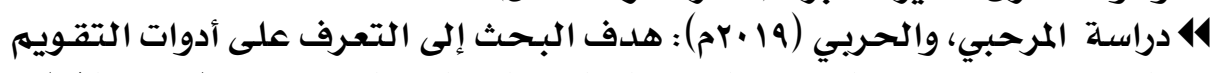

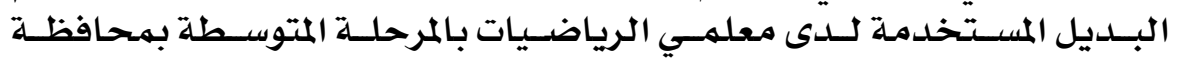

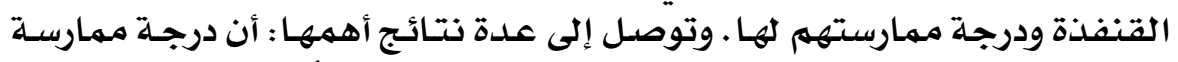

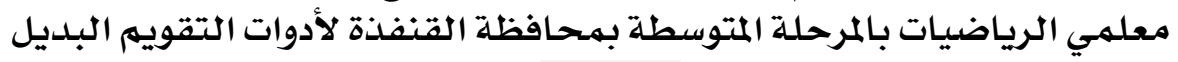

\section{$10 \&$}




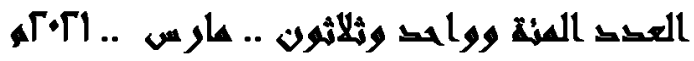

ككل كانت بتقدير ضعيف، وأشارت النتائج إلى وجود فروق دالة إحصائياً عند

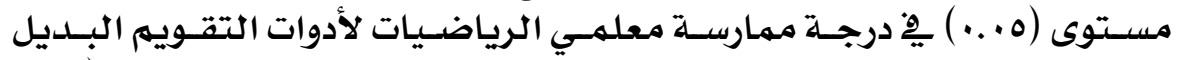

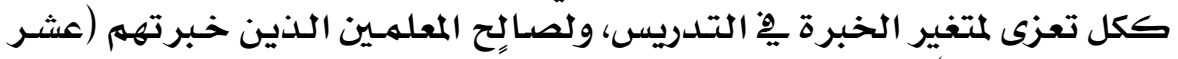

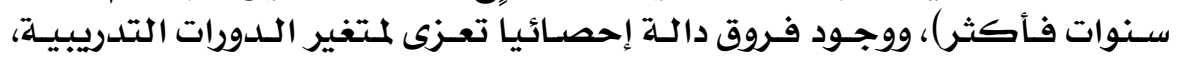

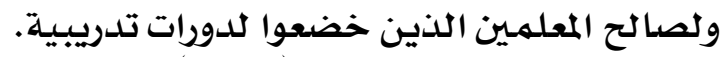

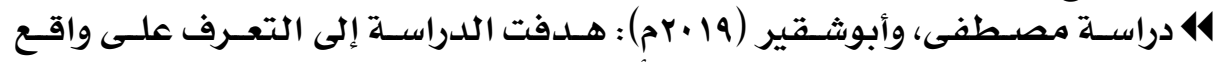

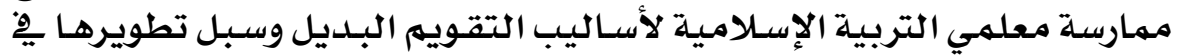

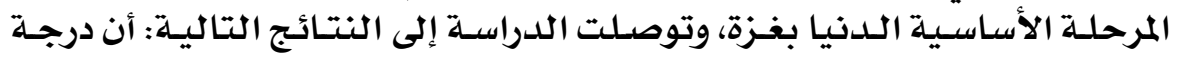

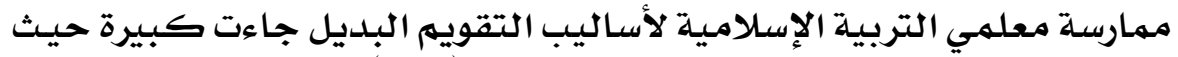

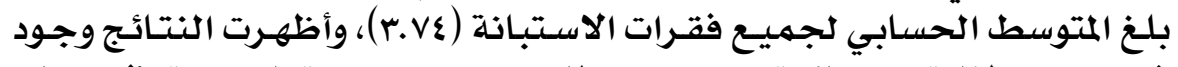

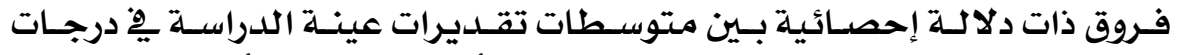

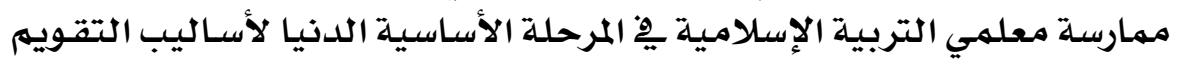

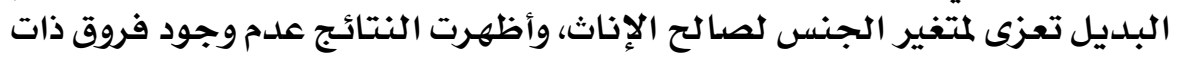

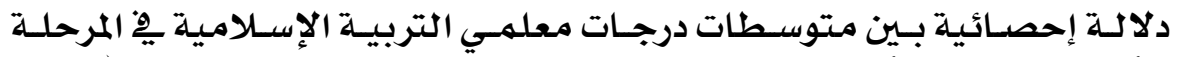

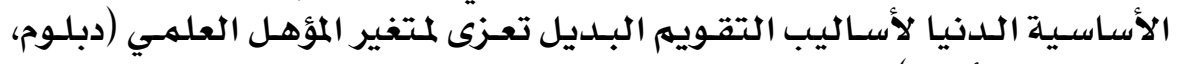

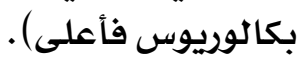

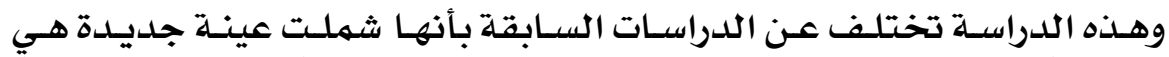

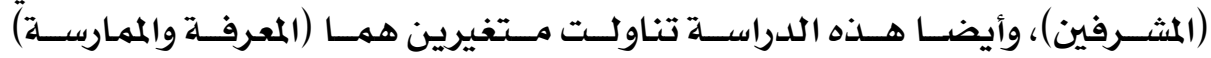

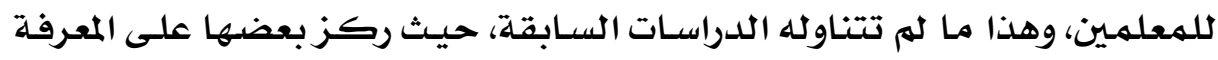

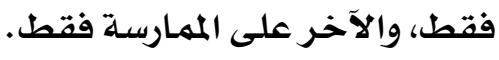

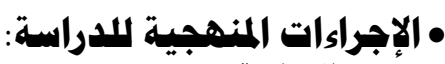
• منّهج الدراسة:

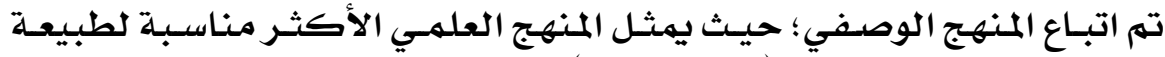

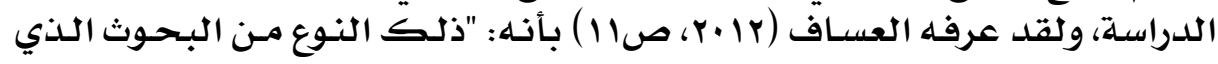

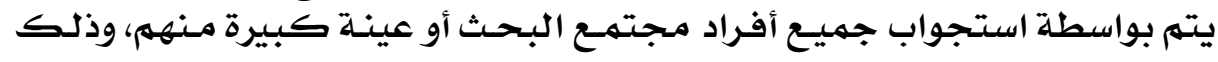

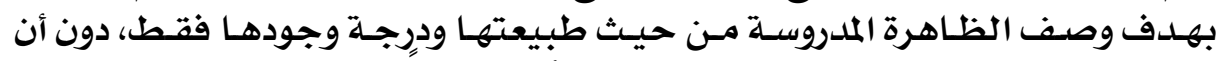

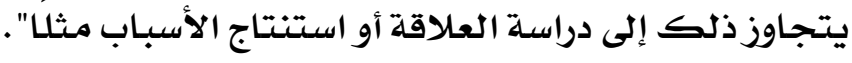

• همتمهم الدراسة:

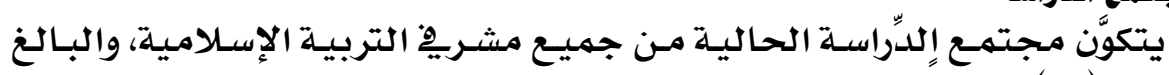

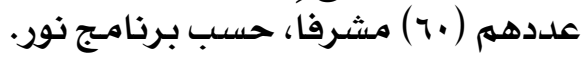
• عينة الدراسة:

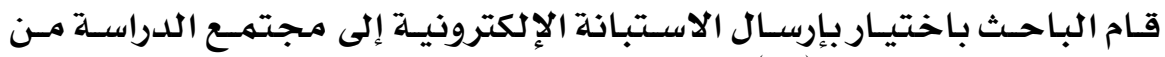

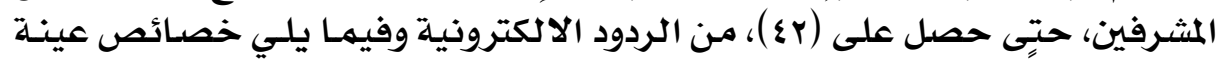

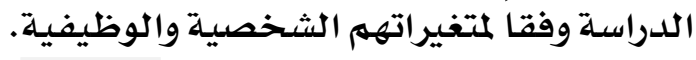

\section{0}




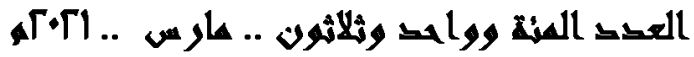

جلول (r) توزيع أفراد عينت الدراستّوفق متغيراتهم الشخصيت والوظيفيت

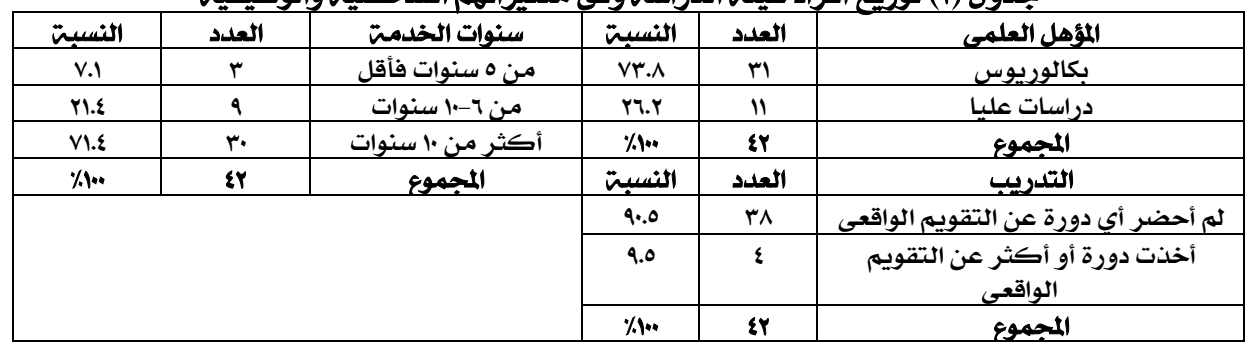

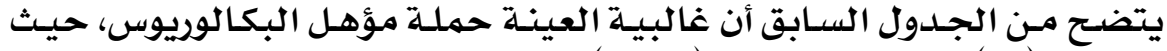

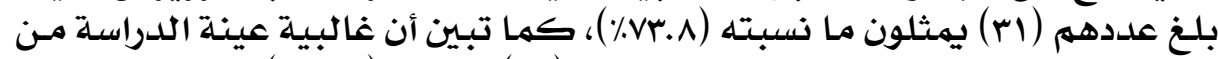

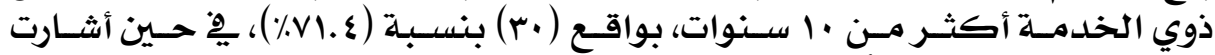

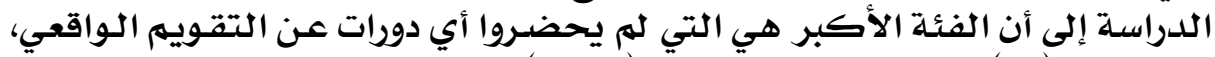

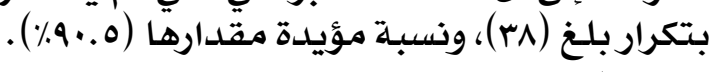

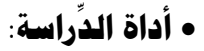

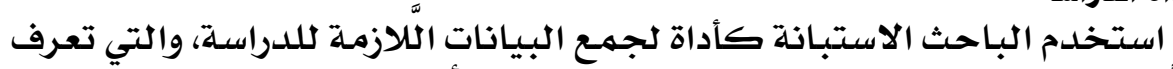

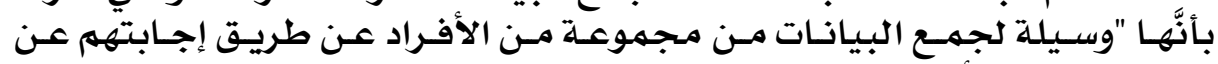

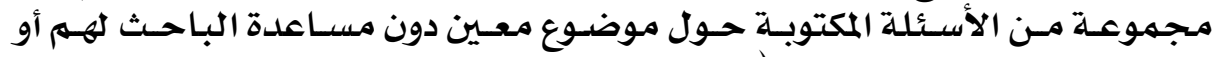

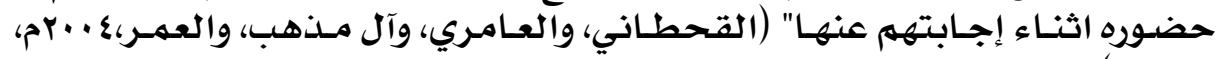

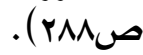

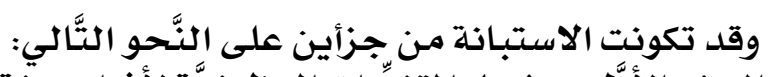

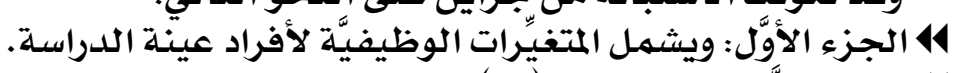

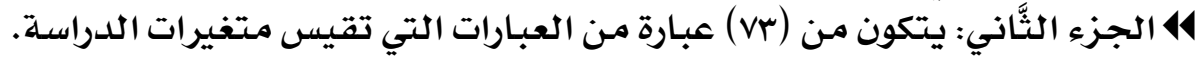

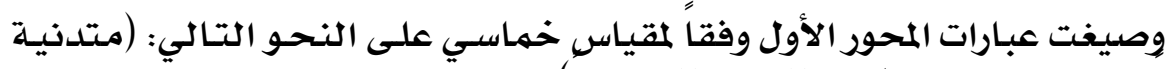

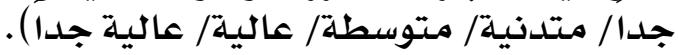

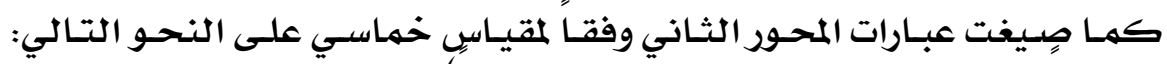

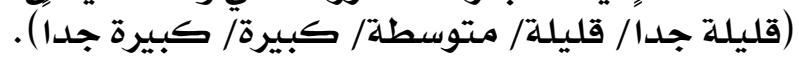

قام الباحث بالتأكد من صداق أداة الداة الدِّراسة بطريقتين:

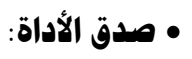

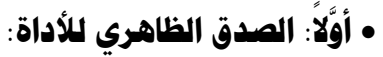

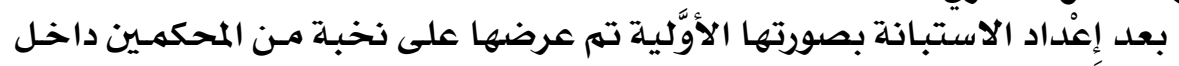

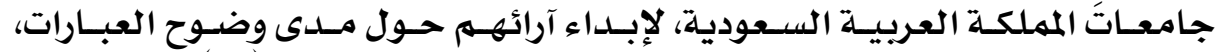

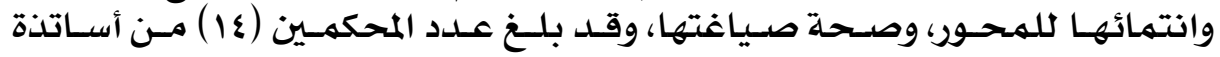
الجامعات السعودية.

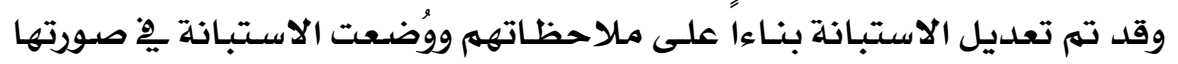

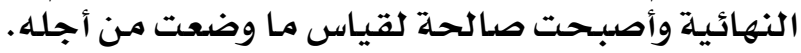

\section{7}




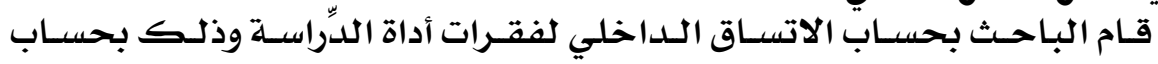

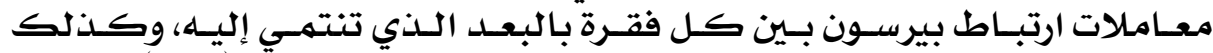

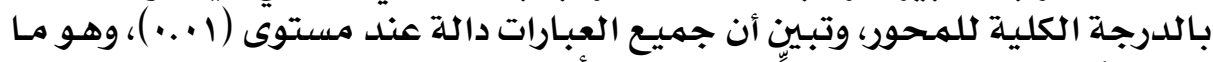

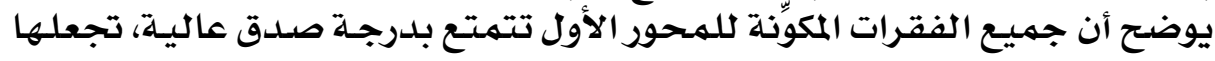

صالحة للتطبيق الميداني.

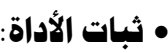

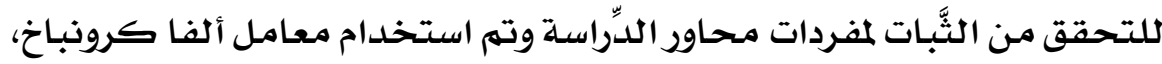

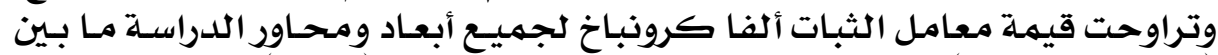

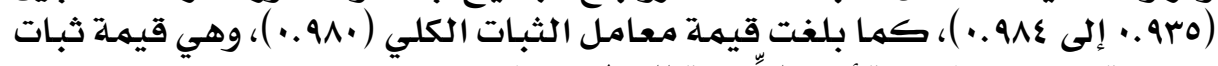

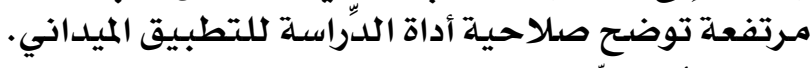

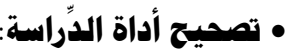

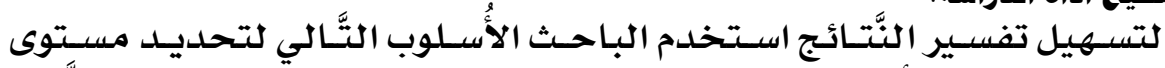

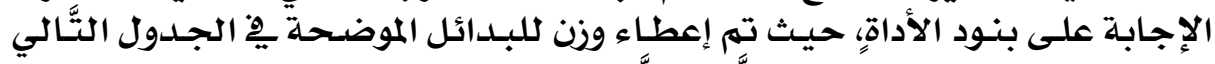

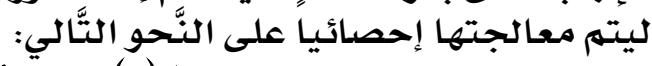
جدول (r) تصحئح أداة الدراستي

\begin{tabular}{|c|c|c|c|c|c|}
\hline متدنيتَجدأ & متدنية/ قليت & متوسطن & عالية/ كبيرة & عاليَّة جداًا. & درجت الوعي/ \\
\hline 1 & $r$ & $r$ & $\varepsilon$ & 。 & الدرجت \\
\hline
\end{tabular}

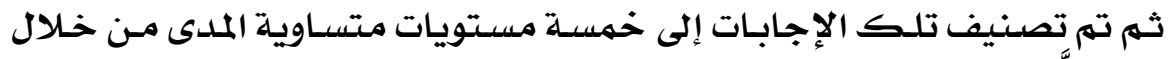

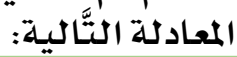

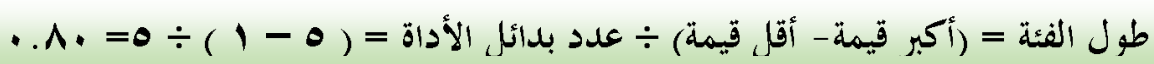
لنحصل على التصنيف التَّالي: جدول (غ) توزيع للفئًات وفق التدرج المستخدم فِ أداة الدرّاستخ

\begin{tabular}{|c|c|}
\hline الحكم & الدرجتً \\
\hline متدنيت جدا/ قليلت جدا & من ...1.1.1. من \\
\hline متدنية/ قليلت & أكبر من •1.1- •r. r. \\
\hline متوسطت & 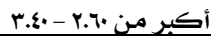 \\
\hline عالية/ كبيرة & أكبر من •.r.r.r.r. \\
\hline عاليتجدا/ كبيرة جدا & 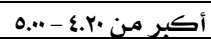 \\
\hline
\end{tabular}

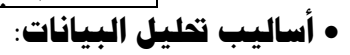

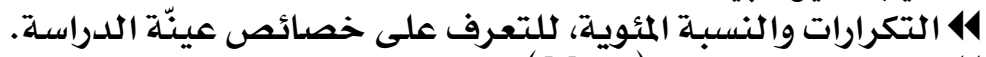

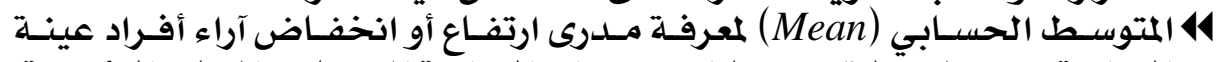

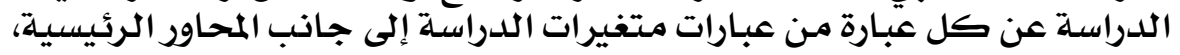

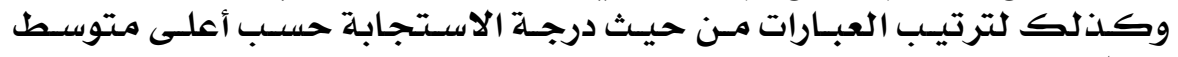
حسابي.

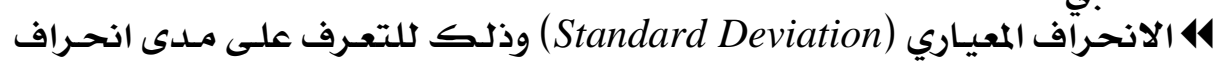

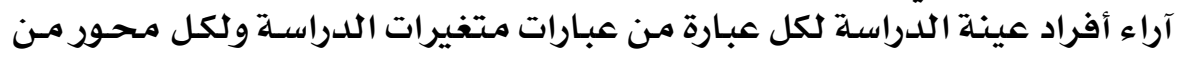

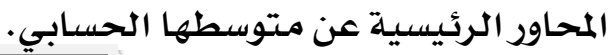


14 معامل ألفا كرونباخ (Cronbach Alpha) لاستخراج ثبات أداة الدراسلة.

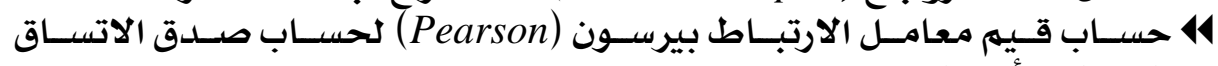

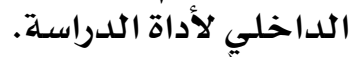

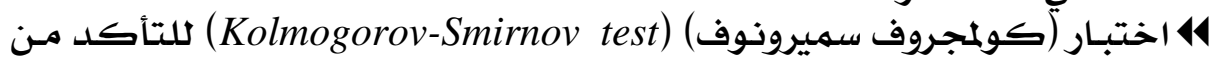

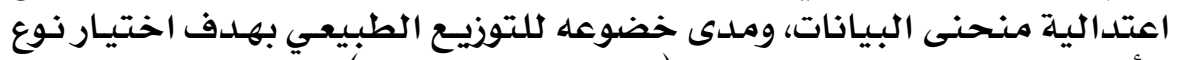

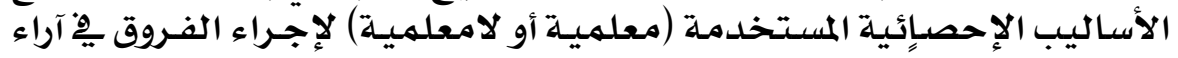

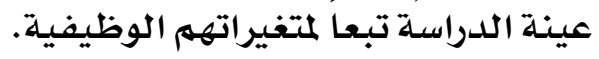

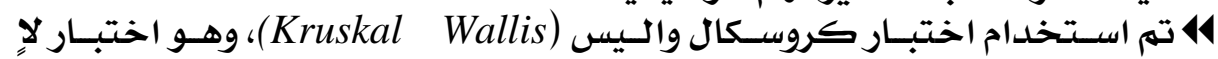

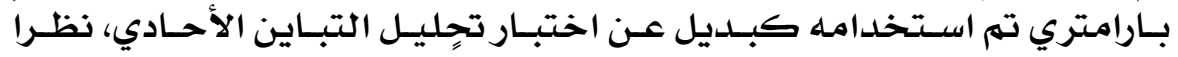

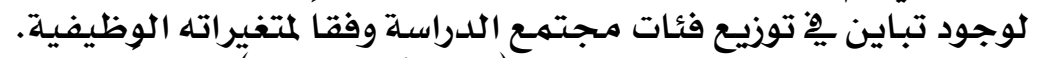

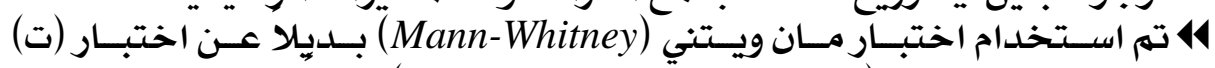

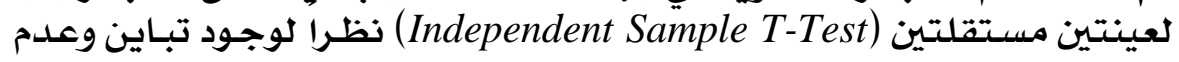

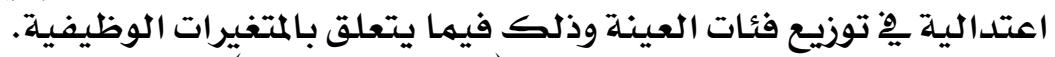

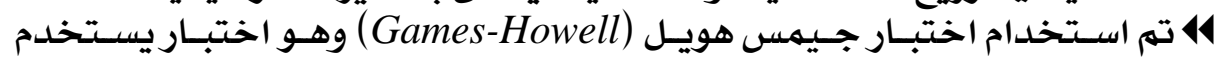

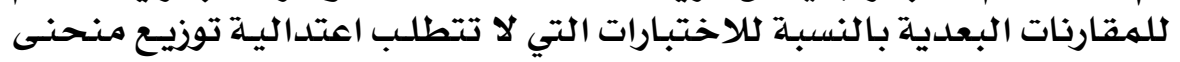

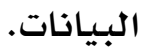

• إجابة السؤال الأول: ها درجة وعي هعلمسي التربيسة الإسـلاهية بمدينسة الريساض باسستراتيجيات

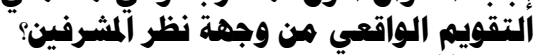

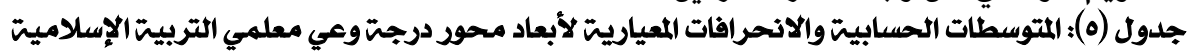

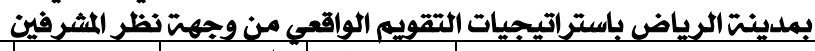

\begin{tabular}{|c|c|c|c|c|}
\hline الترتيب & الورجى & الانحياري & الحسوسطى & البعد \\
\hline$\varepsilon$ & متوسطت & $1 .+17$ & r.r. & استراتيجيت التقويم المعتمد على الأداء \\
\hline 0 & متوسطت & $1.7 \varepsilon$ & r.r. & استراتيجيت مراجعت الذات \\
\hline$r$ & متوسطت & 1.19 & r.r. & استراتيجيت التقويم بالتواصل \\
\hline 1 & عاليت & 1.rYq & r.v乏 & استراتيجيت التقويم بالورقت والقلهم \\
\hline r & عاليتة & $1.11 \mathrm{r}$ & r.\$7 & استراتيحيت التقويم بالملاحظت \\
\hline \multicolumn{2}{|c|}{ لماليت } & $.9 V Y$ & r.\&r & المتوسط الكلى لجميع الأبعاد \\
\hline
\end{tabular}

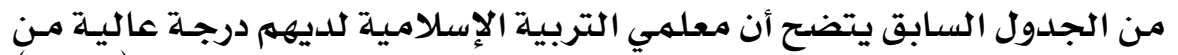

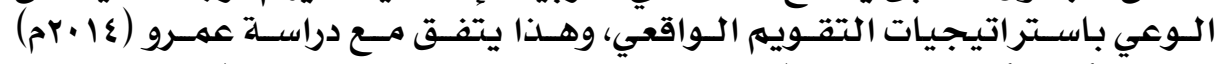

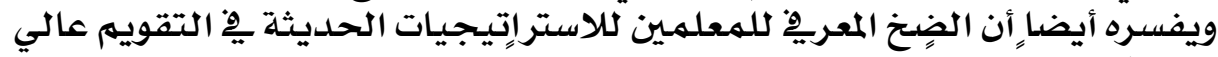

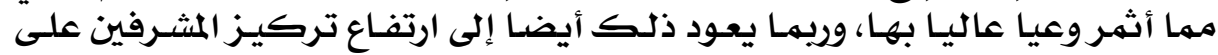

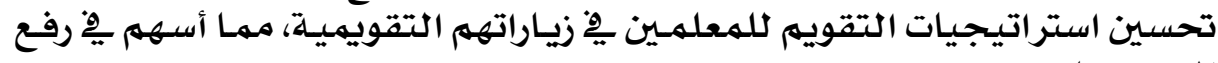
الوعي بها.

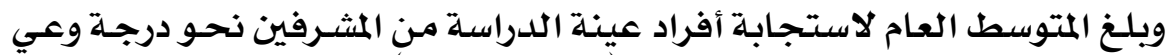

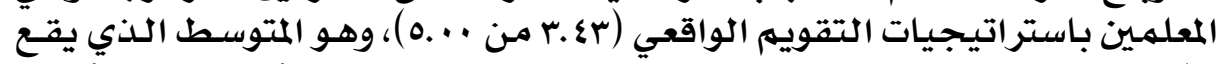

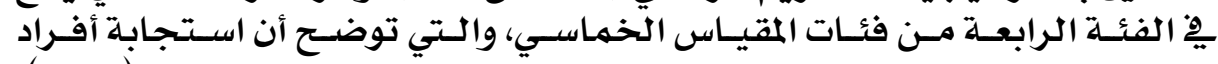

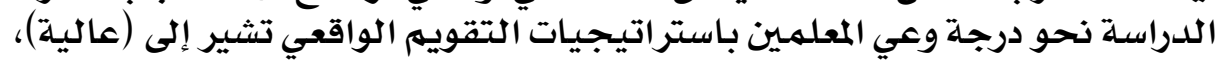

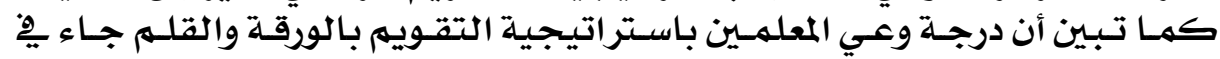




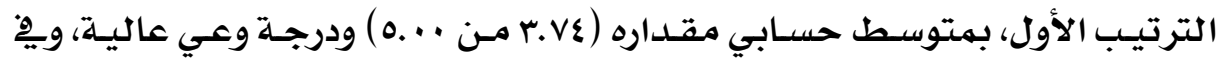

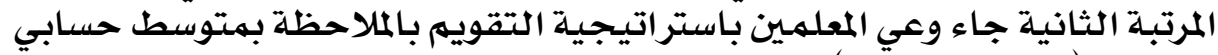

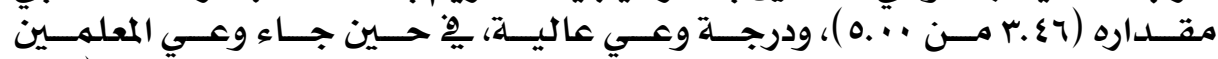

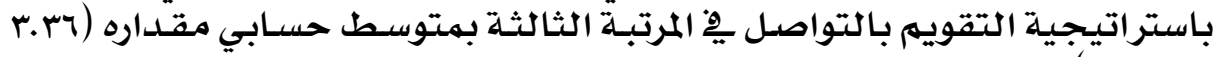

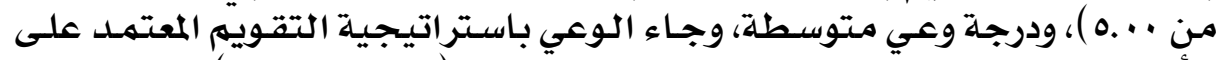

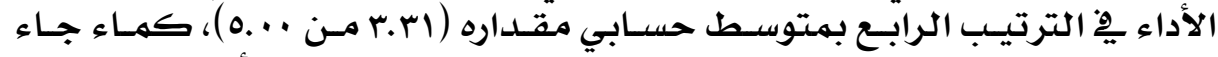

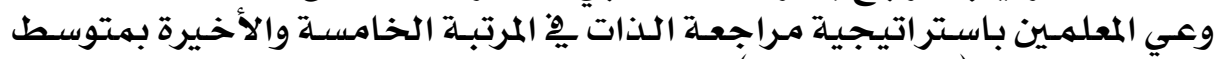

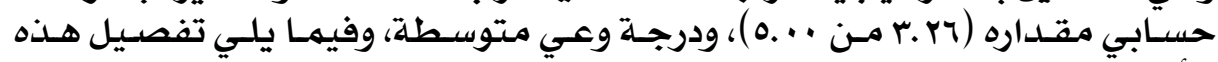

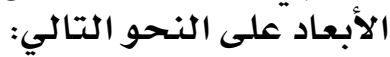

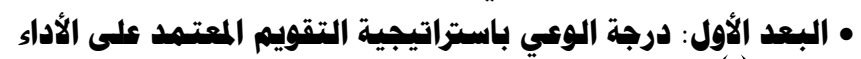

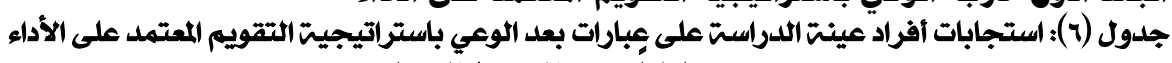
مرتبتّ تنازليا حسب المتوسط الحسابي

\begin{tabular}{|c|c|c|c|c|c|c|c|c|c|c|c|}
\hline \multirow[b]{2}{*}{ الرتبتة } & \multirow[b]{2}{*}{ دالوجي } & \multirow[b]{2}{*}{ الالانحراف } & \multirow{2}{*}{ الحسابيه } & \multicolumn{5}{|c|}{ درجت الومى } & التكرار & \multirow[b]{2}{*}{ العبارة } & \\
\hline & & & & عداليّا & عاليتة & متوسطتة & متدنيت & متدثية & $\%$ & & \\
\hline \multirow[b]{2}{*}{1} & \multirow[b]{2}{*}{ عالية } & \multirow[b]{2}{*}{ 1.1.\% } & \multirow[b]{2}{*}{$r . \& r$} & $r$ & 10 & 11 & $v$ & $r$ & ك & أســــــــــيع & \\
\hline & & & & M.V & ro.v & M.Y & 17.V & \&.A & $\%$ & 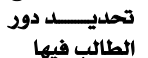 & $r$ \\
\hline \multirow[b]{2}{*}{$r$} & \multirow[b]{2}{*}{ متوسطت } & \multirow[b]{2}{*}{ 1.rer } & \multirow[b]{2}{*}{ ה מ.r } & 11 & 1. & 1. & 1 & - & ك & ارىى أن & \\
\hline & & & & r..Y & rr.A & 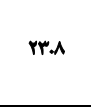 & 18.r. & 11.9 & $\%$ & 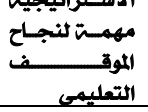 & ○ \\
\hline \multirow[b]{2}{*}{$r$} & \multirow[b]{2}{*}{ متوسطت } & \multirow[b]{2}{*}{$1 . \& 4$} & \multirow[b]{2}{*}{ r.pa } & $\Lambda$ & - & $n$ & 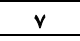 & 1 & ك & امتلكك المعرفة & \\
\hline & & & & 19.. & 11.9 & 0.0 & 17.V & r.\& & $\%$ & تطبيقهإجراءات & 1 \\
\hline \multirow[b]{2}{*}{$\varepsilon$} & \multirow[b]{2}{*}{ متوسطت } & \multirow[b]{2}{*}{$1 . \wedge r$} & \multirow{2}{*}{ r.r } & 9 & 11 & 10 & $\Lambda$ & $r$ & ك & أســـــــــــيع & \\
\hline & & & & 1E.r & ru.r & ro.v & 19. & \&.A & $\%$ & تالمعلم فيهـيـلــ دور & r \\
\hline \multirow[b]{2}{*}{ - } & \multirow[b]{2}{*}{ متدنيت } & \multirow[b]{2}{*}{$1.11 \mathrm{\varepsilon}$} & \multirow[b]{2}{*}{ r..19 } & $\Lambda$ & 1 & iv & $\wedge$ & $r$ & ك & أســـــــــــيع & \\
\hline & & & & 19. & 18.r. & $\varepsilon .0$ & 19.0 & v.1 & $\%$ & 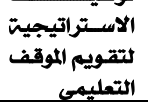 & $\varepsilon$ \\
\hline \multicolumn{2}{|c|}{ متوسطتة } & דיזי1. & $r . r$ & \multicolumn{8}{|c|}{ المتوسط ل المط } \\
\hline
\end{tabular}

هالمتوسط الحسابي من (...0.).

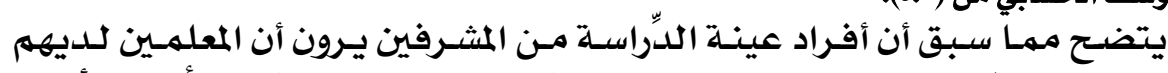

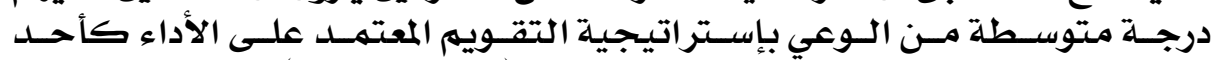

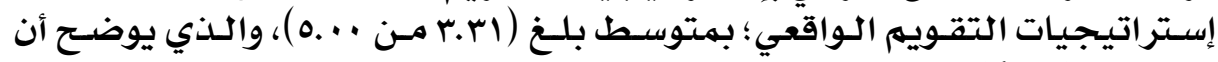

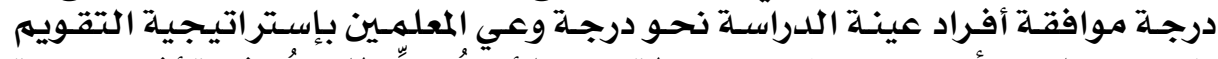

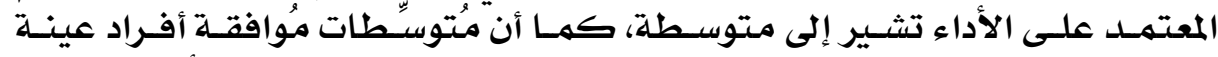

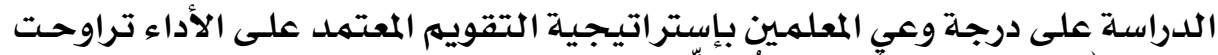

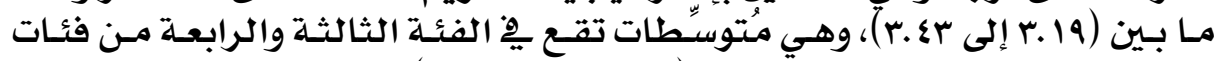

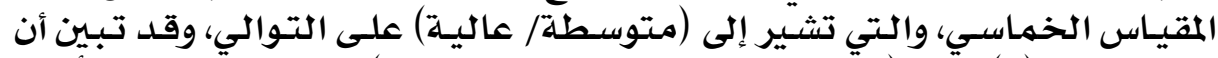

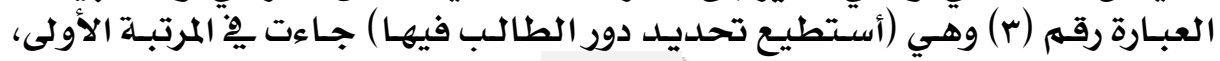

\section{9}




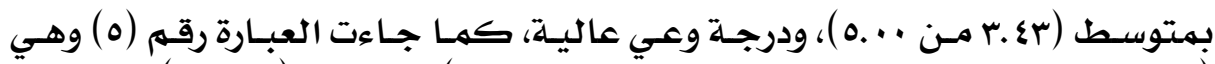

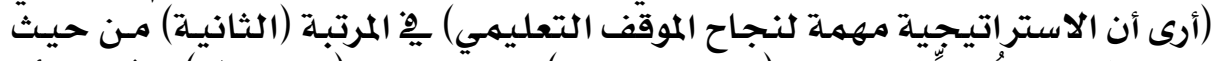

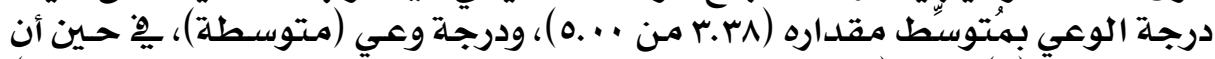

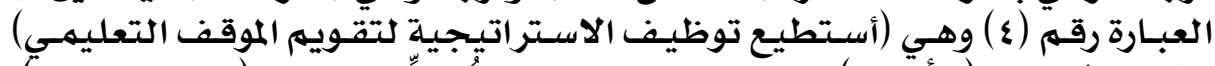

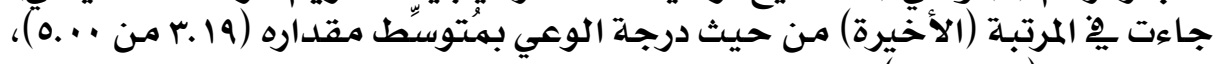
ودرجة وعي (متوسطة) مخيرة)

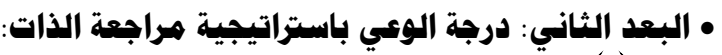

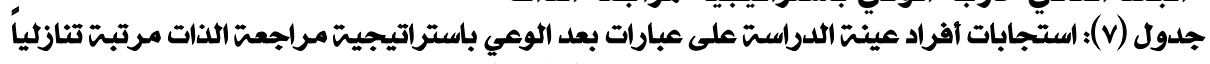

\begin{tabular}{|c|c|c|c|c|c|c|c|c|c|c|c|}
\hline \multirow[b]{2}{*}{ الرتبت } & \multirow[b]{2}{*}{ دالوجي } & \multirow{2}{*}{ الالانحياري } & \multirow{2}{*}{ الحسابيه } & \multicolumn{5}{|c|}{ درجتا ألوعي } & التكرار & \multirow[b]{2}{*}{ العبارة } & \multirow[b]{2}{*}{ م } \\
\hline & & & & عدالية & عاليت & متوسطنة & متدنيت & متدثنية & $\%$ & & \\
\hline \multirow[b]{2}{*}{1} & \multirow[b]{2}{*}{ متوسطت } & \multirow[b]{2}{*}{ 1.rm } & \multirow[b]{2}{*}{ r.s. } & 1. & 9 & 10 & $\varepsilon$ & $\varepsilon$ & ك & \multirow{2}{*}{ 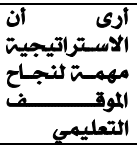 } & \multirow[b]{2}{*}{ 。 } \\
\hline & & & & rr.A & r.S & ro.v & 9.0 & 9.0 & $\%$ & & \\
\hline \multirow[b]{2}{*}{$r$} & \multirow[b]{2}{*}{ متوسطنة } & \multirow[b]{2}{*}{$1 . \times 8$} & \multirow[b]{2}{*}{ r.r } & $v$ & $\Lambda$ & 19 & $\begin{array}{lll} & \\
\end{array}$ & 1 & ك & \multirow{2}{*}{ 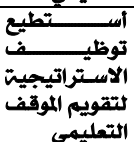 } & \multirow[b]{2}{*}{$\varepsilon$} \\
\hline & & & & 17.V & 19. & \&o.r & 17.V & $r . \varepsilon$ & $\%$ & & \\
\hline \multirow[b]{2}{*}{$r$} & \multirow{2}{*}{ متوسطت } & \multirow[b]{2}{*}{ L.WV. } & \multirow[b]{2}{*}{ r.rr } & $\Lambda$ & 9 & ir & $1 \cdot$ & $r$ & ك & \multirow{2}{*}{ 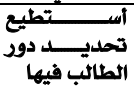 } & \multirow[b]{2}{*}{$r$} \\
\hline & & & & 19. & r..\& & m. & rW.A & E.A & $\%$ & & \\
\hline \multirow[b]{2}{*}{$\varepsilon$} & \multirow[b]{2}{*}{ متوسطت } & \multirow[b]{2}{*}{ 1.1.1. } & \multirow[b]{2}{*}{ r.r } & $\bar{v}$ & 1. & $i r$ & 9 & $r$ & ك & \multirow{2}{*}{ 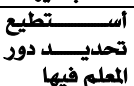 } & \multirow[b]{2}{*}{$r$} \\
\hline & & & & T.V. & rr.A & r.. & Y.E & v.l & $\%$ & & \\
\hline \multirow[b]{2}{*}{ - } & \multirow[b]{2}{*}{ متوسطت } & \multirow[b]{2}{*}{ 1.1.1\& } & \multirow[b]{2}{*}{ r.. } & $\mathrm{v}$ & 7 & 10 & $\pi$ & $r$ & st & \multirow{2}{*}{ 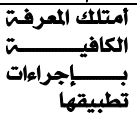 } & \\
\hline & & & & 17.V & 18.r & ro.v & Y.T & \&.A & $\%$ & & 1 \\
\hline & 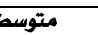 & $1.1 .7 \varepsilon$ & r.Y & & & & & المتوسط & & & \\
\hline
\end{tabular}

هالمتوسط الحسابي من (...0).

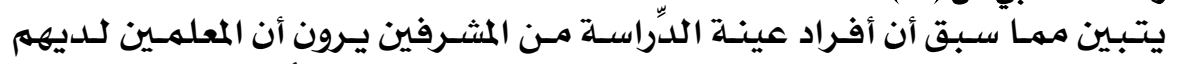

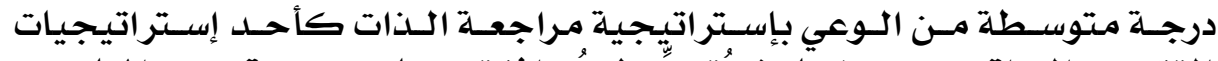

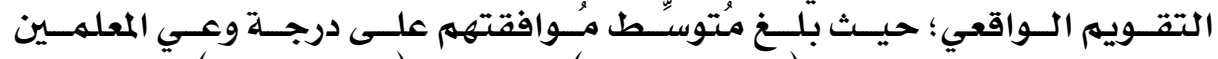

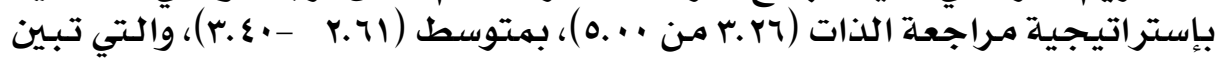

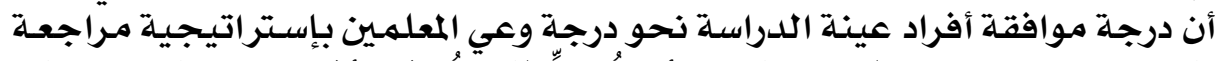

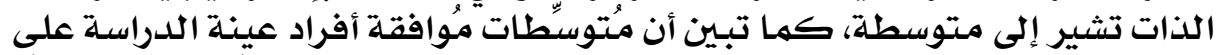

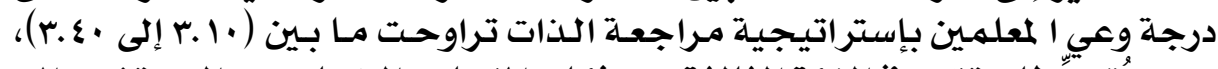

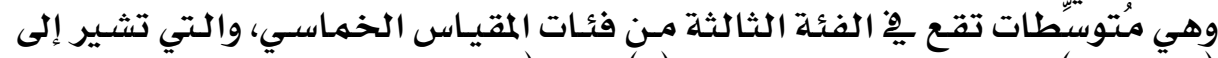

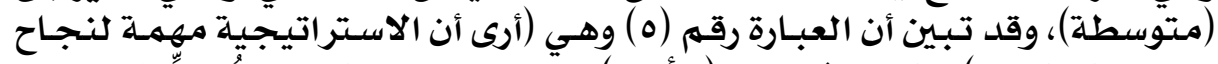

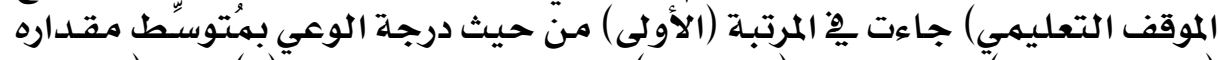

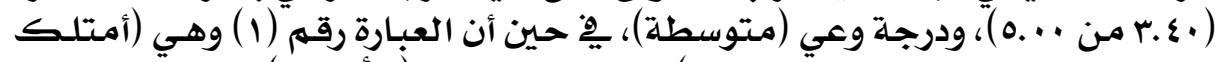

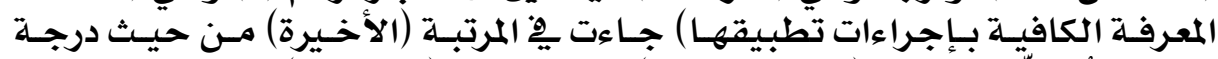

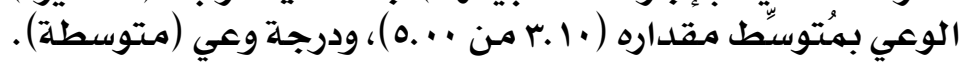




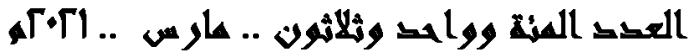

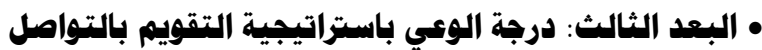

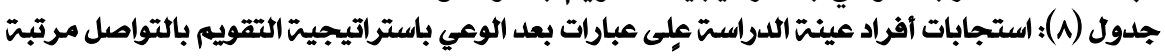

\begin{tabular}{|c|c|c|c|c|c|c|c|c|c|c|c|}
\hline \multirow[b]{2}{*}{ الرتبت } & \multirow[b]{2}{*}{ الوعي } & \multirow[b]{2}{*}{ الانحراف } & \multirow[b]{2}{*}{ الحستوسطي هابط } & \multicolumn{5}{|c|}{ درجت الوعي } & التكرار & \multirow[b]{2}{*}{ العبارة } & \multirow[b]{2}{*}{$p$} \\
\hline & & & & عالية & عاليت & متوسطت & متدثيت & متلدية & $\%$ & & \\
\hline \multirow[b]{2}{*}{1} & \multirow[b]{2}{*}{ عاليت } & \multirow[b]{2}{*}{$1.10 \mathrm{r}$} & \multirow[b]{2}{*}{ r.o. } & 4 & ir & 17 & 1 & $\varepsilon$ & ك & \multirow{2}{*}{ 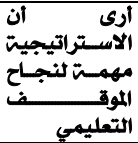 } & \\
\hline & & & & Yl.E & YA.T & rA.I & r.. & 9.0 & $\%$ & & - \\
\hline \multirow[b]{2}{*}{$r$} & \multirow[b]{2}{*}{ عاليت } & \multirow[b]{2}{*}{1.101} & \multirow[b]{2}{*}{ r.sr } & $\Lambda$ & Ir & 17 & $r$ & $\varepsilon$ & ك & \multirow{2}{*}{ 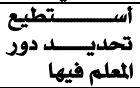 } & \multirow[b]{2}{*}{$r$} \\
\hline & & & & 19." & YA.T & rA.I & $\varepsilon .1$ & 9.0 & $\%$ & & \\
\hline \multirow[b]{2}{*}{$r$} & \multirow[b]{2}{*}{ متوسطة } & \multirow[b]{2}{*}{ 1.rur } & \multirow[b]{2}{*}{ r.my } & $v$ & 9 & $r \cdot$ & $\varepsilon$ & $r$ & ك & \multirow{2}{*}{ 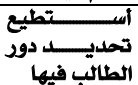 } & \multirow[b]{2}{*}{$r$} \\
\hline & & & & 17.V & Yl.E & \&V.T & 9.0 & \&.A & $\%$ & & \\
\hline \multirow[b]{2}{*}{$\varepsilon$} & \multirow[b]{2}{*}{ متوسطتة } & \multirow[b]{2}{*}{1.110} & \multirow[b]{2}{*}{ r.YA } & $v$ & 1. & $M$ & $r$ & 0 & ك & \multirow{2}{*}{ 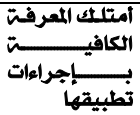 } & \multirow[b]{2}{*}{1} \\
\hline & & & & 17.V & rr.A & \&Y.9 & \&.1 & 11.9 & $\%$ & & \\
\hline \multirow[b]{2}{*}{0} & \multirow[b]{2}{*}{ متوسطتة } & \multirow[b]{2}{*}{$1.1 \leqslant \varepsilon$} & \multirow[b]{2}{*}{ r.YE } & $\Lambda$ & 7 & 19 & 1 & $r$ & ك & \multirow{2}{*}{ 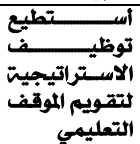 } & \\
\hline & & & & 19. & 1E.r & \&0.Y & |E.r & V.1 & $\%$ & & $\varepsilon$ \\
\hline \multicolumn{2}{|c|}{ متوسطت } & 1.19 & r.My & \multicolumn{6}{|c|}{ المتوسط العام } & & \\
\hline
\end{tabular}

هامتوسط الحسابي من (...0).

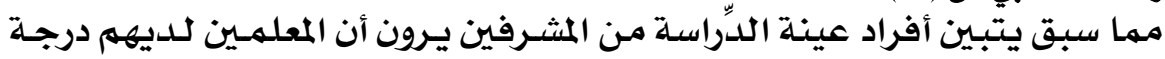

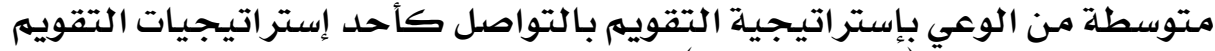

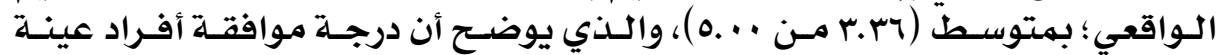

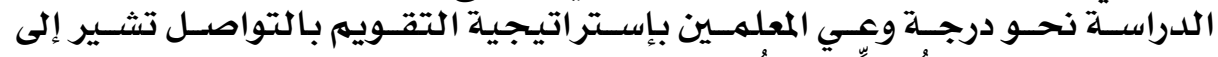

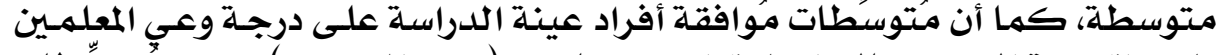

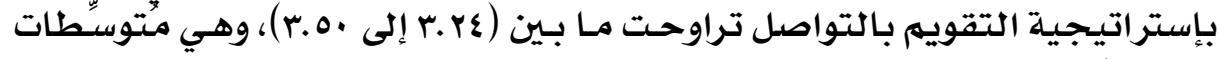

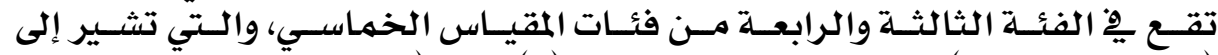

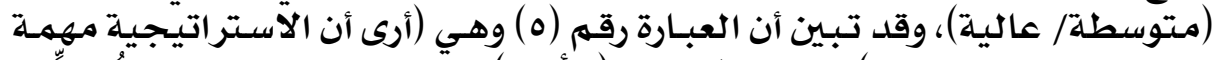

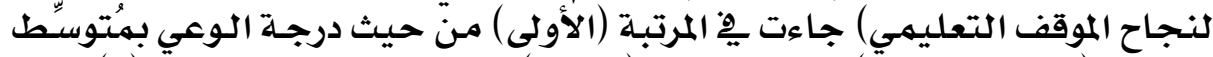

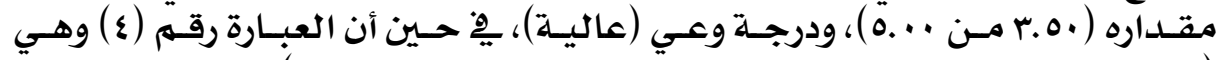

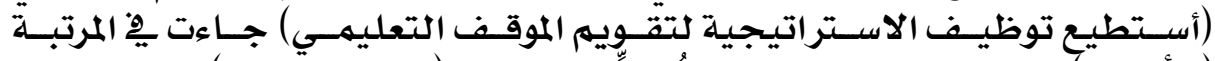

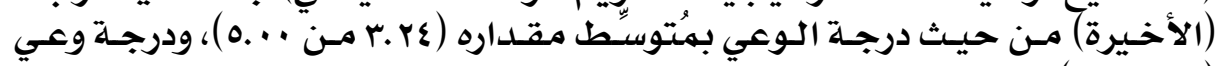
(متوسطة).

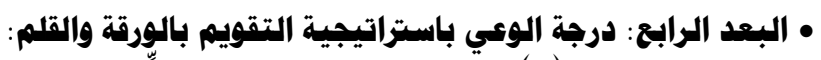

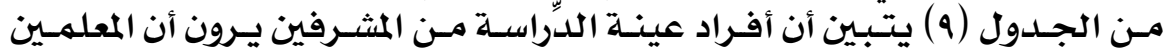

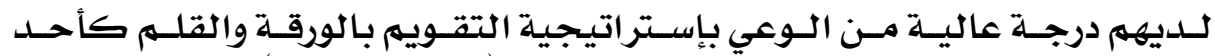

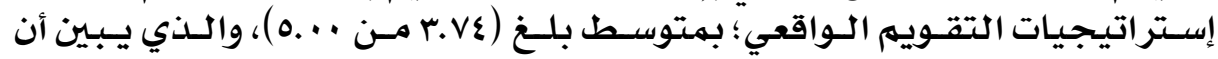

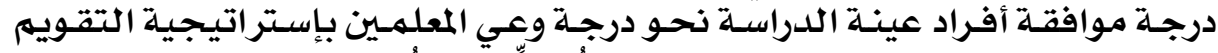

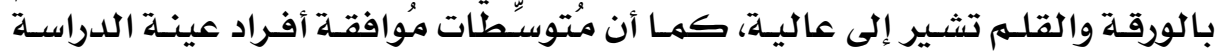




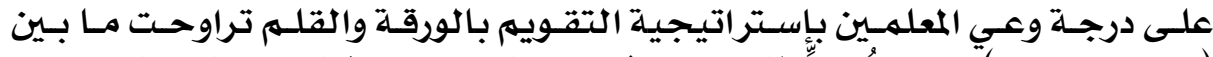
(r.ov)

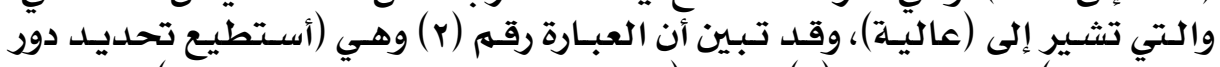

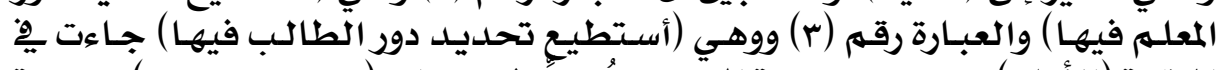

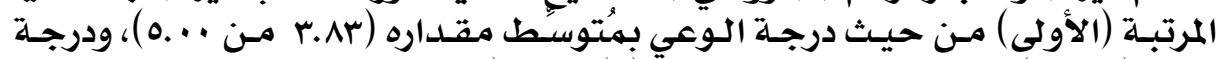

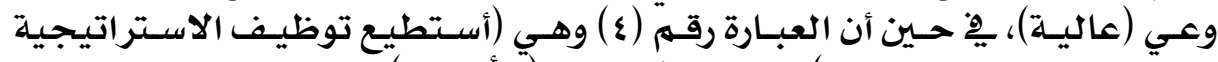

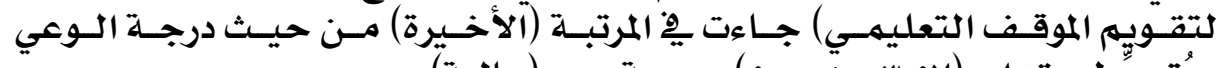

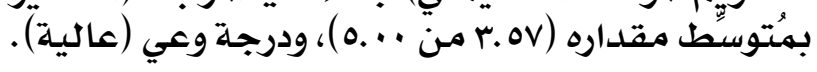

جلول (ه): استجابات أفراد عينت الدراست على عبارات بعد الوعي باستراتيجيت التقويم بالورقت والقلم

\begin{tabular}{|c|c|c|c|c|c|c|c|c|c|c|c|}
\hline \multirow[b]{2}{*}{ الرتبت } & \multirow{2}{*}{ الورجي } & \multirow{2}{*}{ الالانحراف } & \multirow{2}{*}{ الحستوبط ه } & \multicolumn{5}{|c|}{ درجت الومي } & التكرار & \multirow[b]{2}{*}{ العبارة } & \multirow[b]{2}{*}{$p$} \\
\hline & & & & عالية & عاليت & متوسطن & متدثيت & متدثية & $\%$ & & \\
\hline \multirow{2}{*}{1} & \multirow{2}{*}{ عالية } & \multirow{2}{*}{ 1.rYY } & \multirow{2}{*}{ r.Ar } & $r$ & 0 & 1. & $\varepsilon$ & $r$ & ك & \multirow{2}{*}{ 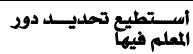 } & \multirow{2}{*}{$r$} \\
\hline & & & & $\varepsilon V . T$ & 11.9 & $r r \cdot A$ & 9.0 & v. & $\%$ & & \\
\hline \multirow{2}{*}{ l } & \multirow{2}{*}{ عالية } & \multirow{2}{*}{ I.YEA } & \multirow{2}{*}{ r.Ar } & 19 & 0 & ir & $\varepsilon$ & $r$ & ك & \multirow{2}{*}{ 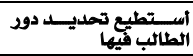 } & \multirow{2}{*}{$r$} \\
\hline & & & & \&0.Y & 11.4 & YM.T & 9.0 & $\varepsilon . \wedge$ & $\%$ & & \\
\hline \multirow[b]{2}{*}{$r$} & \multirow[b]{2}{*}{ عالية } & \multirow[b]{2}{*}{ 1.rry } & \multirow[b]{2}{*}{ r.v\& } & 17 & 11 & $\mathrm{v}$ & $\varepsilon$ & $\varepsilon$ & ك & \multirow{2}{*}{ 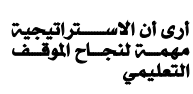 } & \multirow[b]{2}{*}{ • } \\
\hline & & & & r..1 & ri.r & 17.V & 9.0 & 9.0 & $\%$ & & \\
\hline \multirow[b]{2}{*}{$r$} & \multirow[b]{2}{*}{ عالية } & \multirow[b]{2}{*}{ 1.rar } & \multirow[b]{2}{*}{$r . v$} & M & $\varepsilon$ & ir & 7 & $r$ & ك & \multirow{2}{*}{ إمتلـك المعرفتـت الكافيـت } & \multirow[b]{2}{*}{1} \\
\hline & & & & \&Y.१ & 9.0 & Y..T & 15.r & \&.A & $\%$ & & \\
\hline \multirow[b]{2}{*}{$\varepsilon$} & \multirow[b]{2}{*}{ عالية } & \multirow[b]{2}{*}{ 1.r.9.9 } & \multirow[b]{2}{*}{ r.ov } & $1 \varepsilon$ & $\Lambda$ & ir & $\varepsilon$ & $\varepsilon$ & ك & \multirow{2}{*}{ 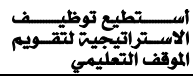 } & \multirow[b]{2}{*}{$\varepsilon$} \\
\hline & & & & rr.r & 14. & Y..T & 9.0 & 9.0 & $\%$ & & \\
\hline & عالي & L.YYM & r.v\& & & & & & لـتوسط الي & & & \\
\hline
\end{tabular}

هابمتوسط الحسابي من (0..0).

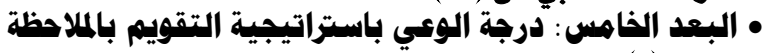

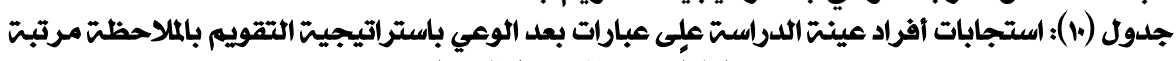

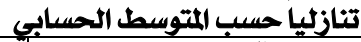

\begin{tabular}{|c|c|c|c|c|c|c|c|c|c|c|c|}
\hline \multirow[b]{2}{*}{ الرتبت } & \multirow{2}{*}{ الومي } & \multirow{2}{*}{ الانمياري } & \multirow{2}{*}{ الحستوسطي المسطي } & \multicolumn{5}{|c|}{ درحت الوعى } & التكراد & \multirow[b]{2}{*}{ العبارة } & \multirow[b]{2}{*}{ p } \\
\hline & & & & حلائت & عاليت & متوسطنة & متدنيت & متلخية & $\%$ & & \\
\hline \multirow[b]{2}{*}{1} & \multirow[b]{2}{*}{ عاليت } & \multirow[b]{2}{*}{1.16.} & \multirow[b]{2}{*}{ r.T. } & ir & $\Lambda$ & ir & $v$ & 1 & 4 & \multirow{2}{*}{ 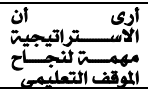 } & \multirow[b]{2}{*}{ 。 } \\
\hline & & & & rl. & 19. & ri.. & 17.8 & Y.E & $\%$ & & \\
\hline \multirow{2}{*}{$r$} & \multirow{2}{*}{ عاليت } & \multirow{2}{*}{1.710} & \multirow{2}{*}{ r.2n } & 1. & ir & $\Lambda$ & 1 & $r$ & t & \multirow{2}{*}{ دور المعليم فيهليـيد } & \multirow{2}{*}{$r$} \\
\hline & & & & $r r . \Lambda$ & ri.० & 19.0 & $Y 1 . \varepsilon$ & $\varepsilon . \Lambda$ & $\%$ & & \\
\hline \multirow[b]{2}{*}{$r$} & \multirow[b]{2}{*}{ عاليت } & \multirow[b]{2}{*}{ 1.1VE } & \multirow[b]{2}{*}{ r.sn } & 1. & 1. & 10 & $\varepsilon$ & $r$ & 4 & \multirow{2}{*}{ 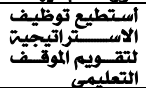 } & \multirow[b]{2}{*}{$\varepsilon$} \\
\hline & & & & rr.A & rr.A & ro.v & 1.0 & V.1 & $\%$ & & \\
\hline \multirow[b]{2}{*}{$\varepsilon$} & \multirow[b]{2}{*}{ متوسطتة } & \multirow[b]{2}{*}{$1.18 \mathrm{~V}$} & \multirow[b]{2}{*}{ r.rA } & $\Lambda$ & Ir & Ir & $\Lambda$ & $r$ & ك & \multirow{2}{*}{ 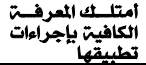 } & \multirow[b]{2}{*}{1} \\
\hline & & & & 19. & YA.T & YA.T & 19. & $\varepsilon . \wedge$ & $\%$ & & \\
\hline \multirow{2}{*}{0} & \multirow{2}{*}{ متوسطة } & \multirow{2}{*}{1.174} & \multirow{2}{*}{ r.rA } & 1. & $V$ & 17 & $v$ & $r$ & ك & \multirow{2}{*}{ 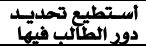 } & \multirow{3}{*}{$r$} \\
\hline & & & & $r r . \Lambda$ & 17.8 & rA.1 & 17.8 & $\varepsilon . \wedge$ & $\%$ & & \\
\hline & عالي & $1.11 \%$ & r.\{7 & & & & & المتوسط & & & \\
\hline
\end{tabular}

هابلمتوسط الحسابي من (ب..0).

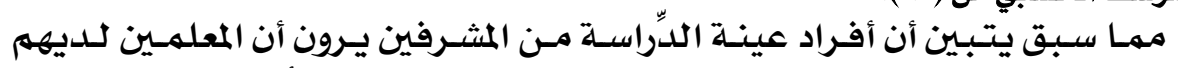

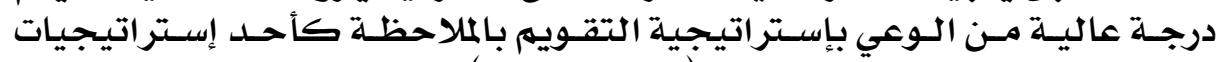

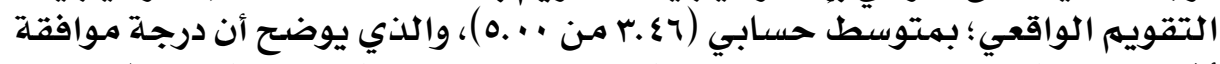

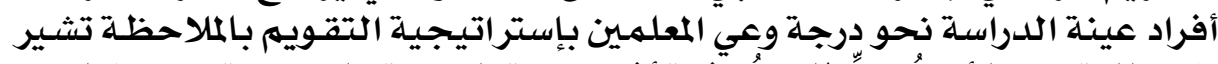

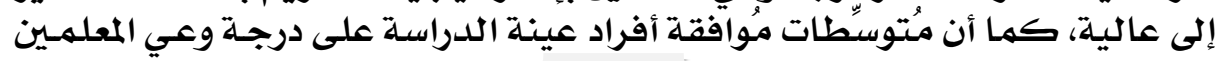




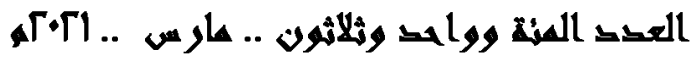

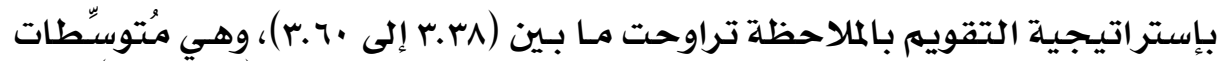

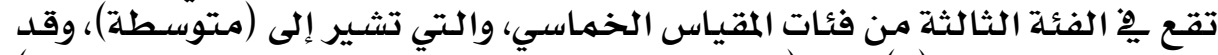

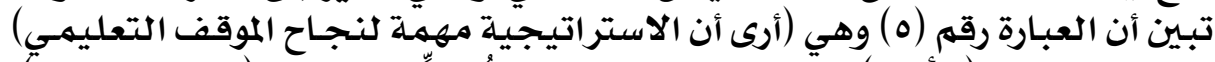

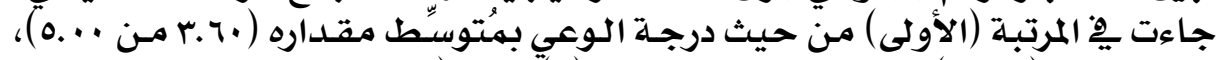

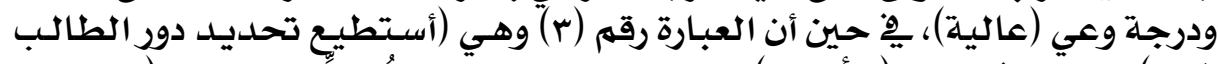

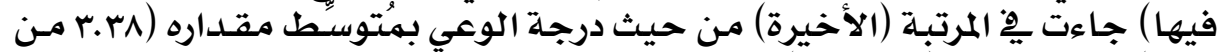

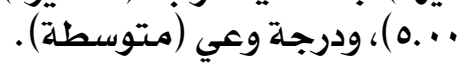

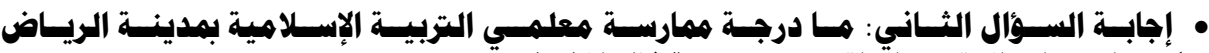

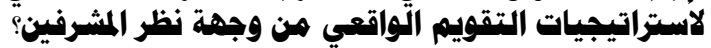

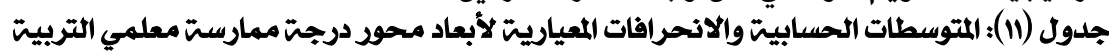

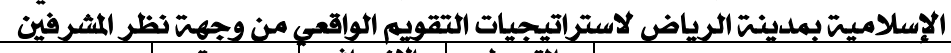

\begin{tabular}{|c|c|c|c|c|}
\hline الترتيب & دارجتَ & الالانحياري & المتوسطى & 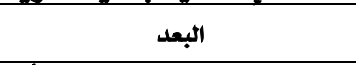 \\
\hline 1 & متدثيت & ..人ar & Y.\$9 & استراتيجيت التقويم المعتمد على الأداء \\
\hline$r$ & متدثيت & $.9 \cdot 7$ & Y.\&A & استراتيحيت مراجعت الذات \\
\hline$\varepsilon$ & متدثيت & $1.11 \mathrm{~V}$ & Y.rE & استراتيحيت التقويى بالتواصل \\
\hline$r$ & متدثيت & $1.0 \% r$ & r.६. & استراتيحيت التقويم بالورقت والقلم \\
\hline 0 & متدثيت & 1..YY & Y.YO & استراتيحيت التقويى بالملاحظت \\
\hline \multicolumn{2}{|c|}{ متدثيت } & •.AAr & r.rq & المتوسط الكلى لجميع الأبعاد \\
\hline
\end{tabular}

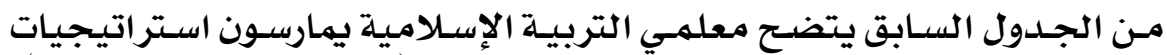

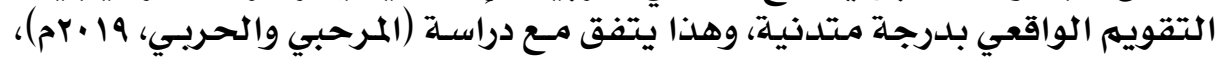

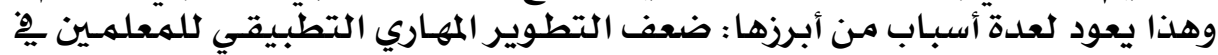

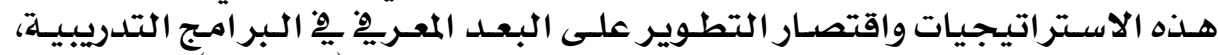

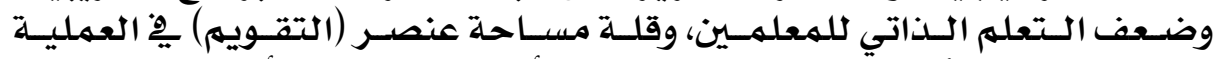

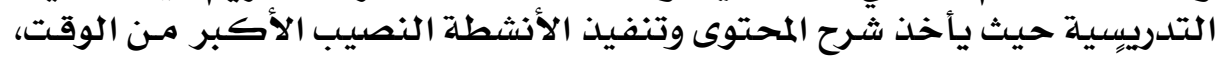

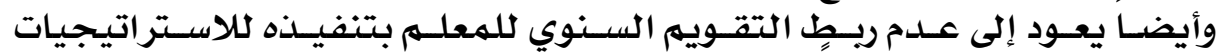

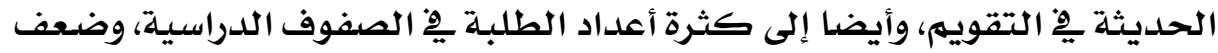

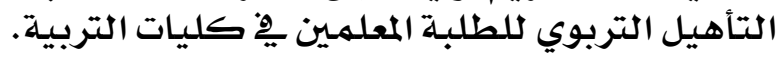

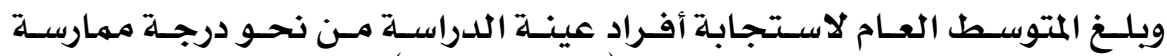

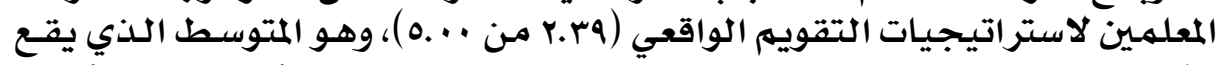

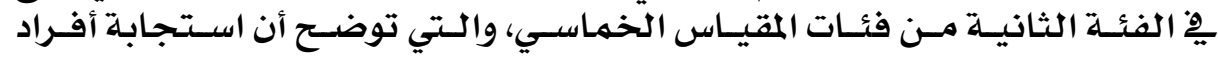

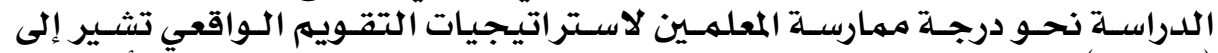

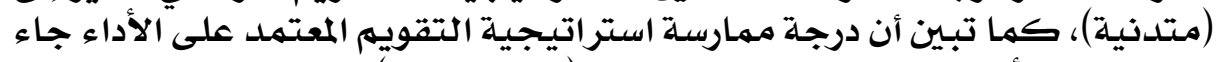

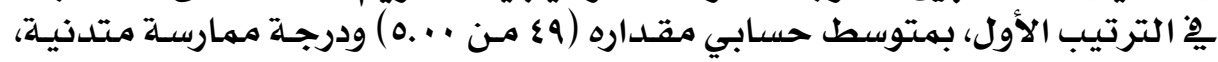

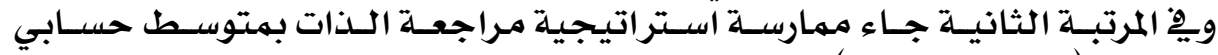

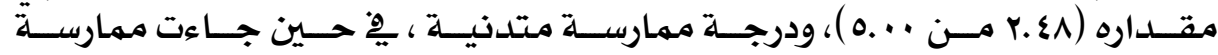

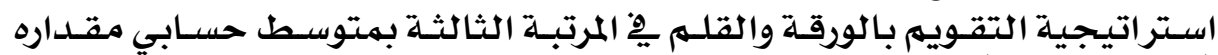

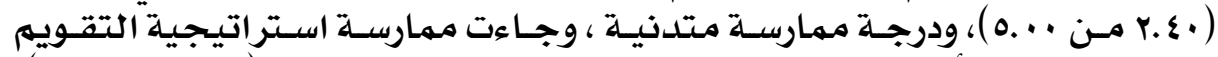

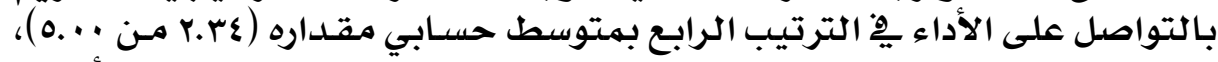

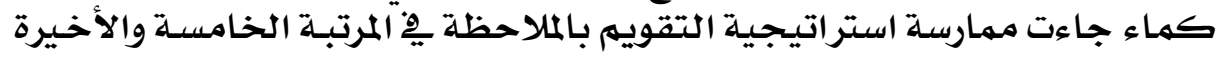




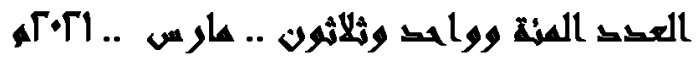

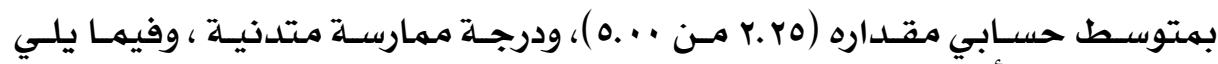

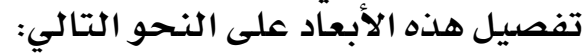

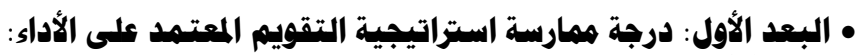

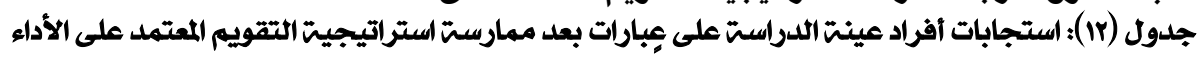

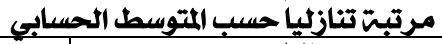

\begin{tabular}{|c|c|c|c|c|c|c|c|c|c|c|c|}
\hline \multirow[b]{2}{*}{ الرتبتة } & \multirow[b]{2}{*}{ الممارجست } & \multirow[b]{2}{*}{ الالانحراف } & \multirow[b]{2}{*}{ الحسابيه } & \multicolumn{5}{|c|}{ درجت الممارست } & \multirow{2}{*}{ \% } & \multirow[b]{2}{*}{ العبارة } & \multirow[b]{2}{*}{ p } \\
\hline & & & & كبيرة & كبيرة & متوسطت & قليلت & جذا & & & \\
\hline \multirow[b]{2}{*}{1} & \multirow[b]{2}{*}{ متوسطت } & \multirow[b]{2}{*}{ 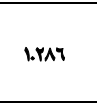 } & \multirow[b]{2}{*}{ r.Ar } & $r$ & 10 & 9 & 7 & 1. & ك & \multirow{2}{*}{ 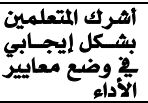 } & \\
\hline & & & & E.A & ro.v & r.. & 1E.r & rr.A & $\%$ & & r \\
\hline \multirow[b]{2}{*}{$r$} & \multirow[b]{2}{*}{ متوسطتة } & \multirow[b]{2}{*}{$1 . r 74$} & \multirow[b]{2}{*}{ r.Tr } & $r$ & 1. & ir & 1 & ir & ك & أكلف المتعلمين & \\
\hline & & & & $\varepsilon .1$ & $r+\Lambda$ & YA.T & 18.r & YA.T & $\%$ & 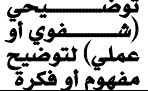 & - \\
\hline \multirow[b]{2}{*}{$r$} & \multirow[b]{2}{*}{ متدنيت } & \multirow[b]{2}{*}{ | } & \multirow[b]{2}{*}{ r. $\%$} & $r$ & $\Lambda$ & 10 & - & ir & ك & أطلــبــــن & \\
\hline & & & & $\varepsilon .1$ & 19.. & ro.v & 11.9 & YA.T & $\%$ & 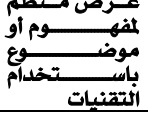 & $r$ \\
\hline \multirow[b]{2}{*}{$\varepsilon$} & \multirow[b]{2}{*}{ متدنيت } & \multirow[b]{2}{*}{ 1.Yo\& } & \multirow[b]{2}{*}{ r.or } & $r$ & $\Lambda$ & it & 1 & ir & ك & أسعى إلى تعزيز & \\
\hline & & & & $\varepsilon .1$ & 19. & ri. & 18.r. & m.. & $\%$ & 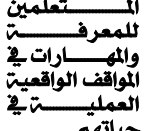 & 9 \\
\hline \multirow[b]{2}{*}{ - } & \multirow[b]{2}{*}{ متدثيت } & \multirow[b]{2}{*}{ l.rar } & \multirow[b]{2}{*}{ r.o. } & $r$ & $v$ & 11 & $\Lambda$ & it & ك & أكلف المتعلمين & \\
\hline & & & & v. 1 & 17.V & r.r. & 19.. & m.. & $\%$ & لإنهاريات المحرفدية & $\varepsilon$ \\
\hline \multirow[b]{2}{*}{1} & \multirow[b]{2}{*}{ متدنية } & & & 1 & 1 & iv & $\begin{array}{ll}v \\
\end{array}$ & 11 & ك & أجري حوارا بين & \\
\hline & & 1.11. & r.o. & r.\& & 1E.r & $\varepsilon .0$ & 17.V & M.Y & $\%$ & 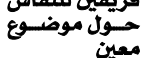 & 9 \\
\hline & & & & $r$ & $v$ & 17 & $r$ & 10 & ك & أزيود المــــعلمين & \\
\hline$v$ & متدثيت & l.rvg & r.o. & \&.A & 17.V & rA.1 & $\varepsilon .1$ & ro.v & $\%$ & 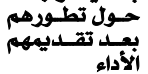 & $"$ \\
\hline & & & & $r$ & 9 & 11 & $\varepsilon$ & 17 & ك & أحسد مــا يـراد & \\
\hline $\mathrm{p}^{\mathrm{v}}$ & متدنيت & 1.rY9 & r.80 & \&.A & Y..E & rT.Y & 9.0 & r. 1 & $\%$ & 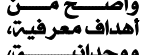 & 1 \\
\hline$\hat{1}$ & متشثتـ & LYYr & $y \leq 0$ & $r$ & $\Lambda$ & 11 & $v$ & 18 & ك & أراقب المتعلمين & 1. \\
\hline$n$ & مستيص & W.rit & 1.80 & $\varepsilon .1$ & 19.. & r... & 17.V & rr.r & $\%$ & أثناء أداء المهمات & 10 \\
\hline & & & & 1 & $v$ & 11 & 9 & $1 \varepsilon$ & ك & أحـوتم المتـعلميين & \\
\hline 9 & متدنية & $1.14 r$ & r.rr & r.६ & 17.V & r..Y & Y.L & rr.r & $\%$ & الأدواركاة ولعب & $\mathrm{v}$ \\
\hline & & & & 1 & $r$ & ir & 1 & 14 & ك & أنظـم معرضـا & \\
\hline 1. & متدنية & 1.1ro & r.vV & r.\& & v.1 & M.. & 1E.r & \&..Y & $\%$ & 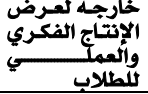 & $\wedge$ \\
\hline & متدذ & r & r..49 & & & & العام العام & المتوس & & & \\
\hline
\end{tabular}

هالمتوسط الحسابي من (..0.). 


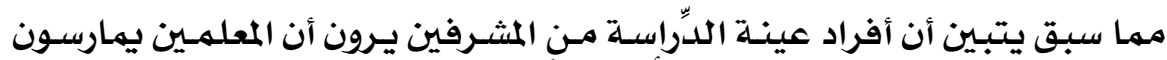

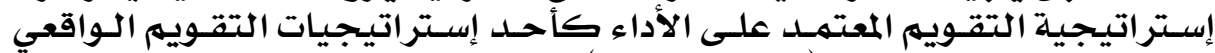

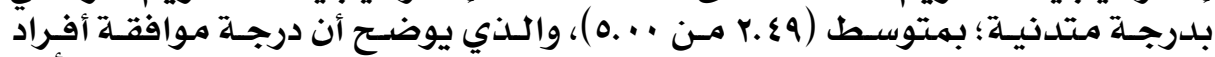

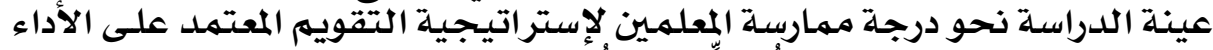

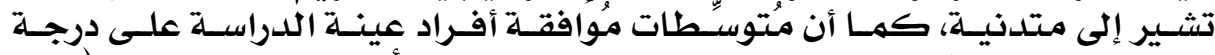

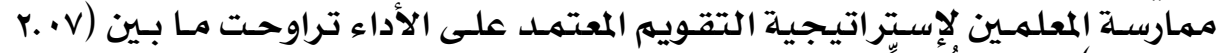

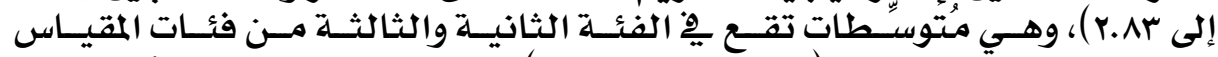

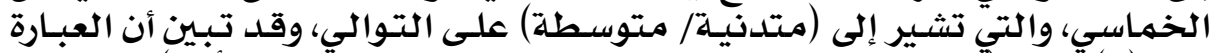

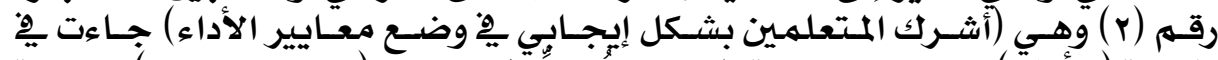

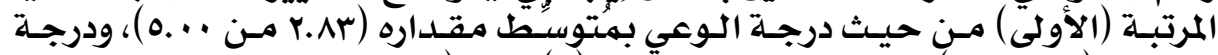

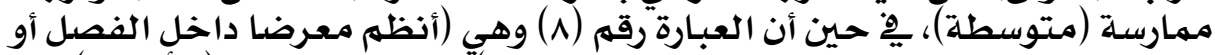

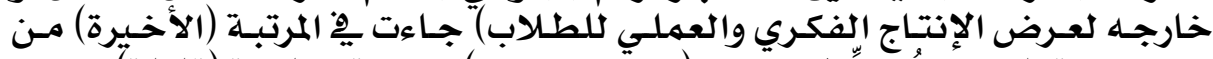

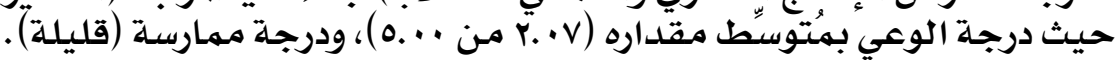

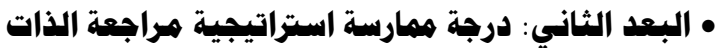

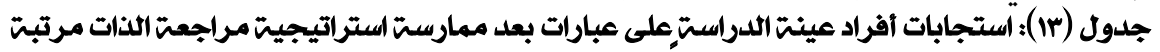

\begin{tabular}{|c|c|c|c|c|c|c|c|c|c|c|c|}
\hline \multirow[b]{2}{*}{ الرتبت } & \multirow[b]{2}{*}{ الممارستة } & \multirow[b]{2}{*}{ الالحيراف } & \multirow[b]{2}{*}{ الحسابيث } & \multicolumn{5}{|c|}{ درجت الممارست } & التكرار & \multirow[b]{2}{*}{ العبارة } & \multirow[b]{2}{*}{ p } \\
\hline & & & & كبيرة & كبيرة & متوسطتة & تليلت & جلية & $\%$ & & \\
\hline \multirow[b]{2}{*}{1} & \multirow[b]{2}{*}{ متوسطة } & \multirow[b]{2}{*}{ 1.r.9.9 } & \multirow[b]{2}{*}{ r.Tr } & 1 & 11 & ir & $\checkmark$ & 11 & ك & \multirow{2}{*}{ 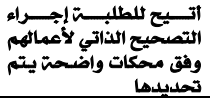 } & \multirow[b]{2}{*}{$\checkmark$} \\
\hline & & & & r.\& & rt.r & YA.T & 17.v & r... & $\%$ & & \\
\hline \multirow[b]{2}{*}{ r } & \multirow[b]{2}{*}{ متدنيت } & \multirow[b]{2}{*}{ I.TYA } & \multirow[b]{2}{*}{ r.ov } & $r$ & 1 & 1. & $\checkmark$ & ir & ك & \multirow{2}{*}{ 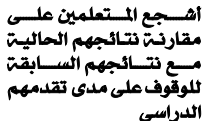 } & \multirow[b]{2}{*}{9} \\
\hline & & & & v.1 & r.. & rr.A & 1r.v & r.. & $\%$ & & \\
\hline \multirow[b]{2}{*}{$r$} & \multirow[b]{2}{*}{ متدنيت } & \multirow[b]{2}{*}{ 1.r.10 } & \multirow[b]{2}{*}{ r.o. } & $r$ & $v$ & ir & $\Lambda$ & ir & ك & \multirow{2}{*}{ 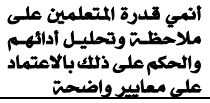 } & \multirow[b]{2}{*}{9} \\
\hline & & & & $\varepsilon .1$ & 17.V & ri.* & 19.0 & YA.T & $\%$ & & \\
\hline \multirow{2}{*}{$\varepsilon$} & \multirow{2}{*}{ متدثيت } & \multirow{2}{*}{$1.10 \mathrm{r}$} & \multirow{2}{*}{ r.2A } & $\cdot$ & 1. & ir & $\Lambda$ & ir & كي & \multirow{2}{*}{ تقويمها نتاجات التعلم المراد } & \multirow{2}{*}{1} \\
\hline & & & & $\because$ & rr.A & YA.T & 19.0 & YA.7 & $\%$ & & \\
\hline \multirow[b]{2}{*}{ - } & \multirow[b]{2}{*}{ متدنيت } & & & 1 & 9 & 18 & $r$ & 10 & ك & الشجع المتعلمين على تقييم & \\
\hline & & 1.Yo\& & r.\&A & r.\& & r.. & r.r. & v.1 & ro.v & $\%$ & لكلف الأعمـال والإنجسازات & ○ \\
\hline & & & & 1 & 1 & is & 11 & 1. & ك5 & أوجـــه تســاؤلات تســـاعد & \\
\hline 1 & متدنيت & $1 \cdots A V$ & r.20 & r.q & le.r & rr.r & ru.r & rr.A & $\%$ & 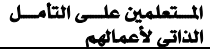 & $\varepsilon$ \\
\hline & & & & $r$ & 1 & ir & A & ir & ك & أوضـح للطلبـتَ كيفيـتً & \\
\hline$v$ & متدثيت & אוץ IT & r.\&r & $\varepsilon .1$ & IE.r & ri." & 14. & ri. & $\%$ & الذاتـخـذام أدوات مراجعــة & $r$ \\
\hline & & & & $r$ & $v$ & ir & 7 & 10 & كـ & أحسدد معـايير ومؤثــرات & \\
\hline$\wedge$ & متدنيتة & 1.Yv. & Y.L. & $\varepsilon .1$ & 17.v & YA.T & 1E.r. & ro.v & $\%$ & لتاجات التعلم مـــــ تحقق & r \\
\hline & & & & $r$ & $\varepsilon$ & $1 \varepsilon$ & 9 & ir & ك & اكلـف المتعلمين بكتابـة & \\
\hline 9 & متدنيت & 1.170 & Y.rY & \&.A & 9.0 & rr.r & r... & ri. & $\%$ & 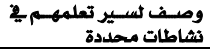 & $\wedge$ \\
\hline & 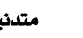 & .9 .7 & r.2A & & & & & 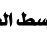 & & & \\
\hline
\end{tabular}

هالمتوسط الحسابي من (ب...0).

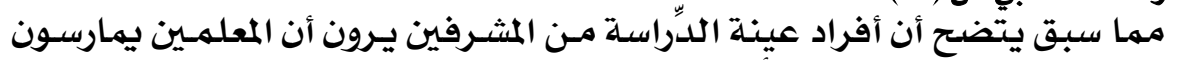

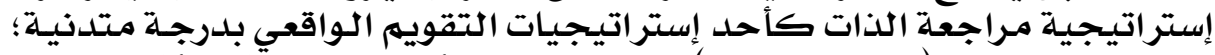

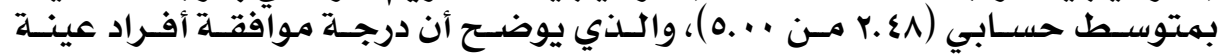




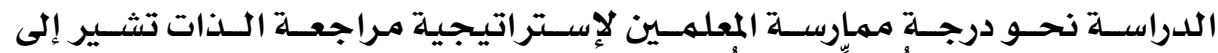

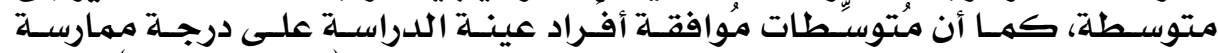

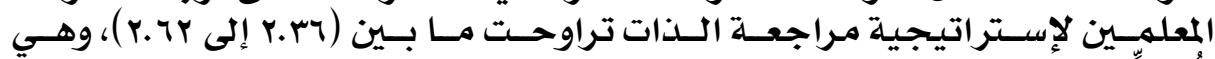

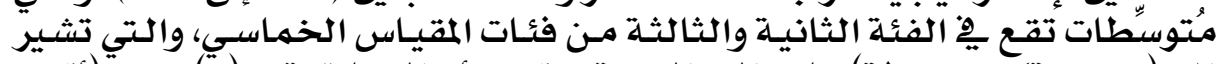

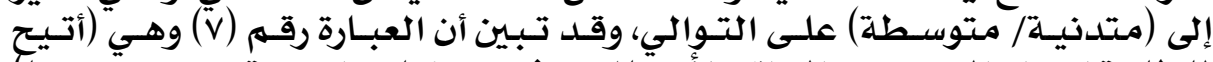

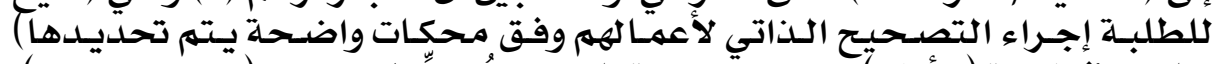

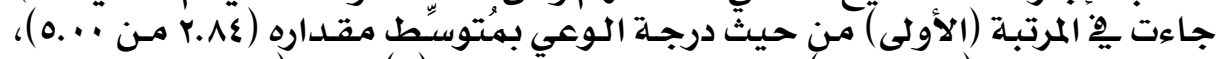

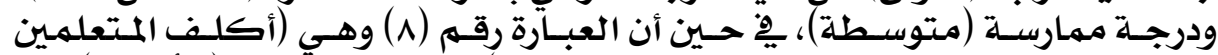

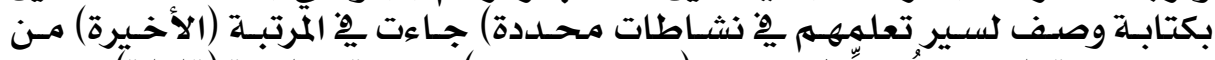

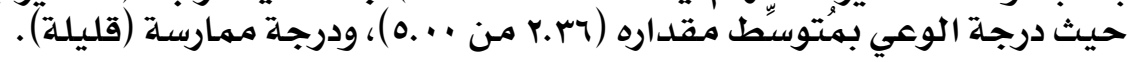

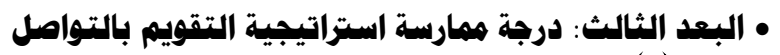

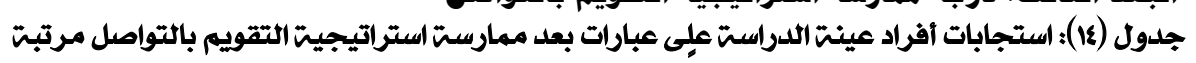

\begin{tabular}{|c|c|c|c|c|c|c|c|c|c|c|c|}
\hline \multirow[b]{2}{*}{ الرتبت } & \multirow[b]{2}{*}{ المماربستة } & \multirow[b]{2}{*}{ الاندصيافي } & \multirow[b]{2}{*}{ الحسعابيط المتوسط } & \multicolumn{5}{|c|}{ درحت الممارستة } & التكراد & \multirow[b]{2}{*}{ العبارة } & \multirow[b]{2}{*}{ p } \\
\hline & & & & كبيرة & كبيرة & متوسطتة & قليلت & جلية & $\%$ & & \\
\hline \multirow[b]{2}{*}{1} & \multirow[b]{2}{*}{ متدنيت } & \multirow[b]{2}{*}{$1 . \varepsilon \Psi V$} & \multirow[b]{2}{*}{ Y.7. } & $r$ & $v$ & $1 \varepsilon$ & 7 & ir & ك & \multirow{2}{*}{ 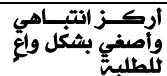 } & \multirow[b]{2}{*}{$r$} \\
\hline & & & & v.1 & 17.V & rr.r & 1E.r & YA.T & $\%$ & & \\
\hline \multirow[b]{2}{*}{$r$} & \multirow[b]{2}{*}{ متدثيت } & \multirow[b]{2}{*}{ 1.รr\& } & \multirow[b]{2}{*}{ Y.o. } & $\cdot$ & $\Lambda$ & IV & 0 & Ir & ك & \multirow{2}{*}{ 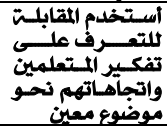 } & \multirow[b]{2}{*}{ 。 } \\
\hline & & & & $\because *$ & 19. & $\varepsilon .0$ & 11.9 & YA.T & $\%$ & & \\
\hline \multirow[b]{2}{*}{$r$} & \multirow[b]{2}{*}{ متدنيت } & \multirow[b]{2}{*}{ 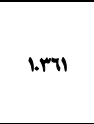 } & \multirow[b]{2}{*}{ T.Y.T } & . & 0 & 19 & $\varepsilon$ & $1 \varepsilon$ & ك5 & \multirow{2}{*}{ 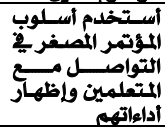 } & \multirow[b]{2}{*}{$\varepsilon$} \\
\hline & & & & $\because$ & 11.9 & \&o.Y & 9.0 & rr.r & $\%$ & & \\
\hline \multirow[b]{2}{*}{$\varepsilon$} & \multirow[b]{2}{*}{ متدنيت } & \multirow[b]{2}{*}{ 1.YAE } & \multirow[b]{2}{*}{ r.rr } & . & 9 & ir & $r$ & IV & ك & \multirow{2}{*}{ 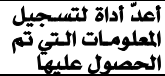 } & \multirow[b]{2}{*}{ r } \\
\hline & & & & $\because$ & Y.E & m.. & v. & $\varepsilon .0$ & $\%$ & & \\
\hline \multirow[b]{2}{*}{0} & \multirow[b]{2}{*}{ متدنيت } & \multirow[b]{2}{*}{ I.rAr } & & . & 1. & 11 & $\varepsilon$ & IV & ك & أستـخدم الأسـئلت & \\
\hline & & & r.rr & $\because$ & rr.A & YT.Y & 9.0 & $\varepsilon .0$ & $\%$ & 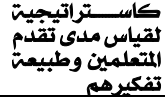 & 7 \\
\hline & & & & - & $v$ & 17 & $r$ & 17 & ك5 & احلد المهمتشواتفق & \\
\hline 7 & متدنيت & 1.rr. & r.rr & $\because$ & 17.V & rA.1 & v. 1 & r..1 & $\%$ & 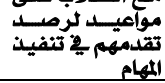 & 1 \\
\hline$v$ & متدنتي & 1.Yor & r.19 & $\cdot$ & 1 & 1. & $r$ & $r$ & ك & 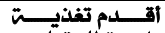 & $\hat{\Lambda}$ \\
\hline$\checkmark$ & مسليص & $1.10 \mathrm{~T}$ & 1.14 & $\because$ & YI.E & rr.n & V.I & $\varepsilon V .7$ & $\%$ & راجعت للمتعلم & $\wedge$ \\
\hline & & & & 1 & 0 & Ir & $r$ & $r$ & ك & أعقــــــــــــــاء & \\
\hline$\wedge$ & متدنيت & 1.r. & Y.H & Y.\& & 11.9 & YA.T & v. 1 & 0.0 & $\%$ & 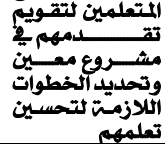 & $v$ \\
\hline & متدث & $1.1 \mathrm{~V}$ & Y.YE & & & & لعام & المتوسط & & & \\
\hline
\end{tabular}

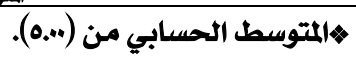

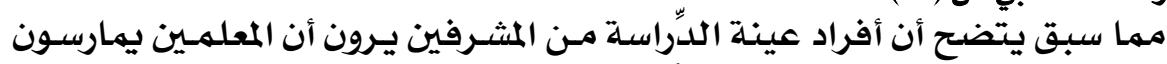

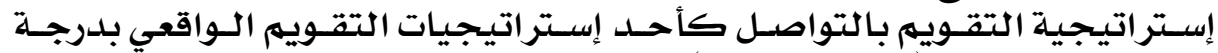

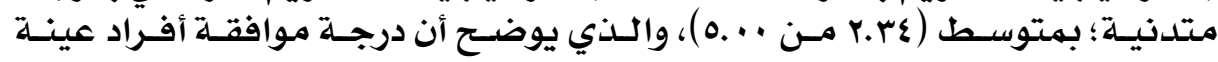




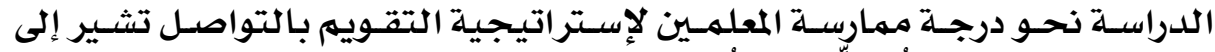

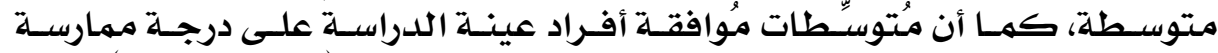

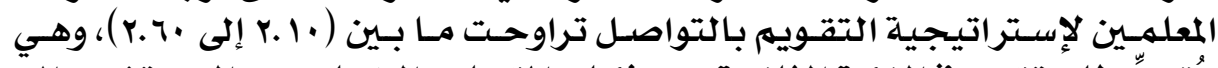

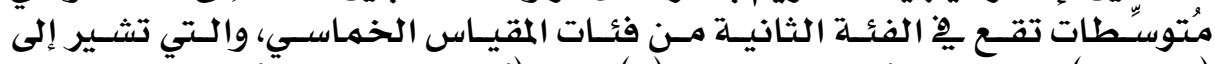

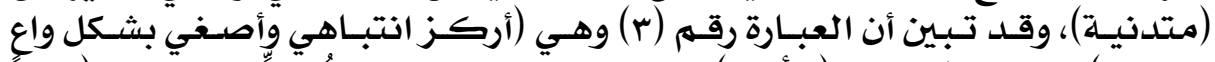

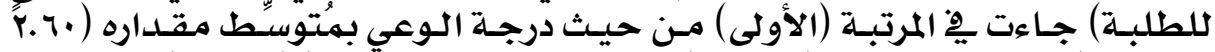

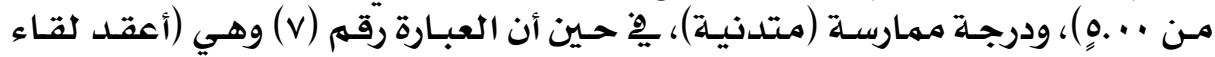

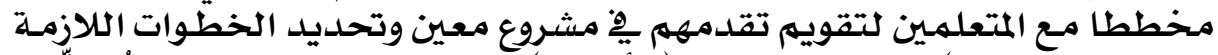

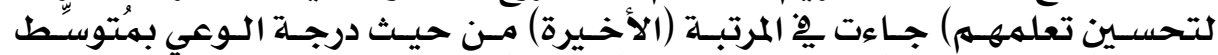

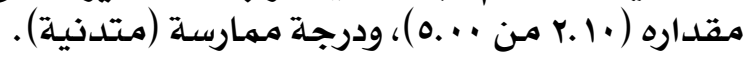

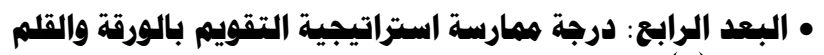

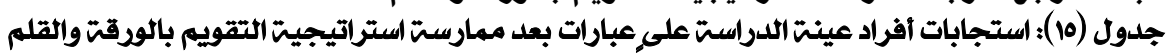

\begin{tabular}{|c|c|c|c|c|c|c|c|c|c|c|c|}
\hline \multirow[b]{2}{*}{ الرتبتة } & \multirow{2}{*}{ الممارستة } & \multirow{2}{*}{ الالانحراف } & \multirow{2}{*}{ الحتوسطي } & \multicolumn{5}{|c|}{ درجت الممارستة } & التكرار & \multirow[b]{2}{*}{ العبارة } & \multirow[b]{2}{*}{$p$} \\
\hline & & & & كبيرة & كبيرة & متوسطنة & قليلت & جليةً & $\%$ & & \\
\hline \multirow[b]{2}{*}{1} & \multirow[b]{2}{*}{ متوسطت } & \multirow[b]{2}{*}{ 1.rAs } & \multirow[b]{2}{*}{ r.vi } & $r$ & 18 & 11 & $\cdot$ & 10 & ك & \multirow{2}{*}{ 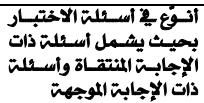 } & \multirow[b]{2}{*}{$\wedge$} \\
\hline & & & & 6.1 & rr.r & ri.r & $\because$ & ro.v & $\%$ & & \\
\hline \multirow{2}{*}{ r } & \multirow{2}{*}{ متدنيت } & \multirow{2}{*}{ 1.r.1. } & \multirow{2}{*}{ r.00 } & 1 & 11 & $1 \varepsilon$ & . & 17 & ك & \multirow{2}{*}{ قياسلهاد نـواتج التعلم المراد } & \multirow{2}{*}{1} \\
\hline & & & & $Y . \xi$ & rq.Y & $r+r . r$ & $\because$ & r..1 & $\%$ & & \\
\hline \multirow[b]{2}{*}{$r$} & \multirow[b]{2}{*}{ متدثيت } & \multirow[b]{2}{*}{ 1. IEA } & \multirow[b]{2}{*}{ r.o. } & 1 & Ir & 11 & 1 & IV & ك & \multirow{2}{*}{ 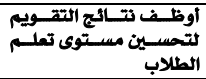 } & \multirow[b]{2}{*}{$" 11$} \\
\hline & & & & r.s & Y⿳.T. & ri.r & r.\& & 8.0 & $\%$ & & \\
\hline \multirow{2}{*}{$\varepsilon$} & \multirow{2}{*}{ متدنيت } & \multirow{2}{*}{1.201} & \multirow{2}{*}{ r.Lr } & $r$ & Ir & $\Lambda$ & $\cdot$ & $r$ & ك & \multirow{2}{*}{ 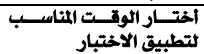 } & \multirow{2}{*}{ I } \\
\hline & & & & $\varepsilon . \Lambda$ & YA.T & 19. & $\because$ & $\varepsilon V . T$ & $\%$ & & \\
\hline 0 & متشنت & res & $x \&$ & $r$ & 1. & 1. & 1 & 14 & ك & أسعى لأن يكون الاختبـار & $x$ \\
\hline 0 & مسلدي & $1.54 \pi$ & T.24 & $\xi .1$ & $r r \cdot \Lambda$ & rr.A & r.\& & 80.Y & $\%$ & شاملاً للنواتج المراد قياسها & $\mathbf{v}$ \\
\hline 7 & تינ: & twas & דו & $r$ & 9 & 11 & $\cdot$ & $r$. & ك & أعمل دائما على أن يتصف & m \\
\hline 9 & 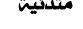 & 1.049 & P.Pq & $\varepsilon .1$ & Y.I. & rq.Y & $\because$ & $\varepsilon V .1$ & $\%$ & الاختبار بالدقت (الثبات) & \\
\hline & & & & 1 & 4 & Ir & $r$ & M & ك & أنوقع بِ مجـالات التقـويم & \\
\hline$\checkmark$ & متدنيت & 1.r.r. & r.r. & r.s & r..\& & rA.T & 纟.A & ¿ห.१ & $\%$ & 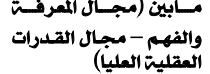 & 9 \\
\hline & & & & 1 & $\Lambda$ & 18 & $\cdot$ & 19 & ك & ألــــوم عنــــد تصــــميم & \\
\hline$\wedge$ & متدنيت & l.r.". & r.rr & Y.\& & 19. & rr.r. & $*$ & \&o.Y & $\%$ & 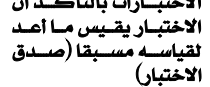 & $r$ \\
\hline & & & & 1 & 11 & 9 & $\cdot$ & $n$ & ك & أعــد نموذجــا لإججابــةت & \\
\hline 9 & متدنيت & 1.rAM & r.M & r.\& & ru.r & M.E & $\because$ & 0.0 & $\%$ & 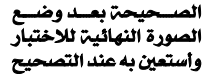 & 1. \\
\hline & & & & 1 & $v$ & ir & $r$ & r. & ك & 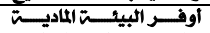 & \\
\hline 1. & 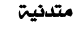 & 1.rva & r.m & r.q & M.V & YA.T & $\varepsilon .1$ & $\varepsilon \vee .4$ & $\%$ & الاختبار النفست المناسبت لتطبيق & 。 \\
\hline & تד & Iras & $Y$ & 1 & $\mathrm{v}$ & in & . & $n$ & ك & احدد مجالات التقويم ب2 & 8 \\
\hline p. & مندليم & $1.104 \mathrm{~A}$ & T.M & r.\& & 17.V & r1. & $\because$ & 0.0 & $\%$ & جدول المواصفات & 8 \\
\hline & متدثي & T.r. & Y.E* & & & & & وسط ال & & & \\
\hline
\end{tabular}

هالمتوسط الحسابي من (ن..0).

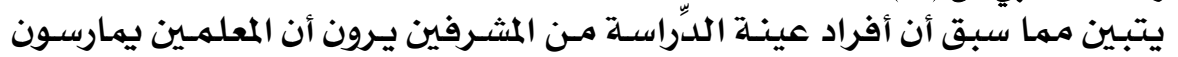

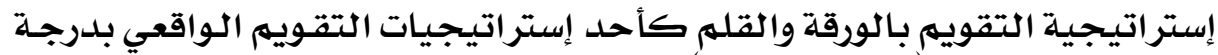

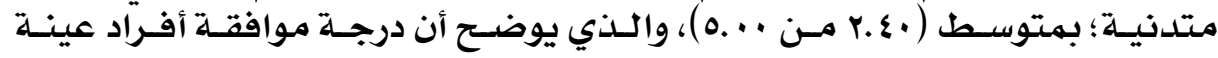

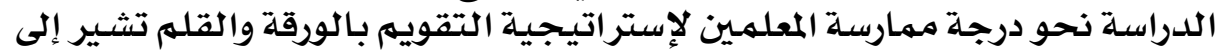




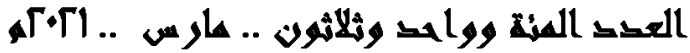

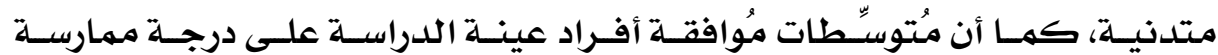

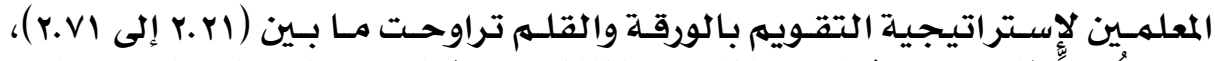

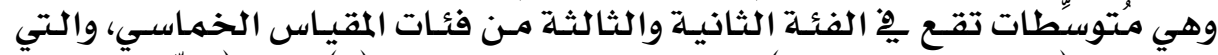

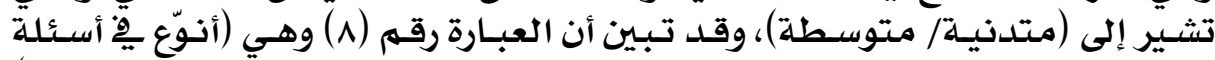

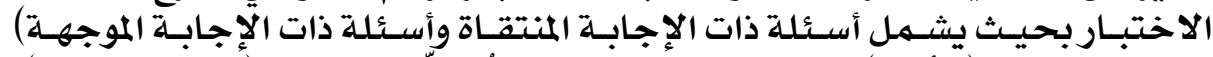

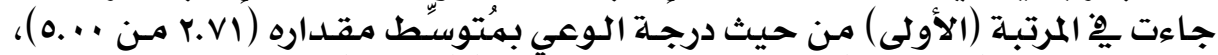

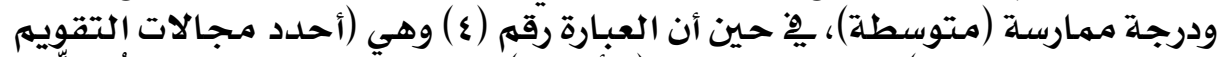

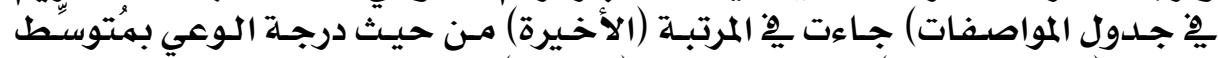

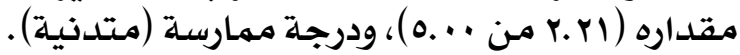

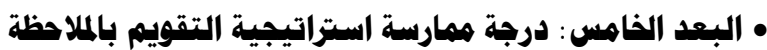

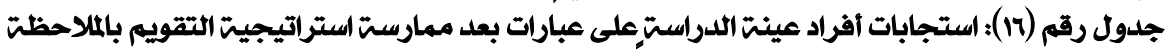
مرتبتّ تنازليا حسب المتوسط الحسابي

\begin{tabular}{|c|c|c|c|c|c|c|c|c|c|c|c|}
\hline \multirow[b]{2}{*}{ الرتبت } & \multirow[b]{2}{*}{ المعارستة } & \multirow[b]{2}{*}{ الالمعياري } & \multirow[b]{2}{*}{ الحسابيه } & \multicolumn{5}{|c|}{ درجت الممارستة } & التكرار - مار & \multirow[b]{2}{*}{ العبارة } & \multirow[b]{2}{*}{ p } \\
\hline & & & & جبيرة & كبيرة & متوسطتة & قليلة & قليًَ & $\%$ & & \\
\hline \multirow[b]{2}{*}{1} & \multirow[b]{2}{*}{ متدنيت } & \multirow[b]{2}{*}{ 1.r" } & \multirow[b]{2}{*}{ r.o. } & . & $1 \varepsilon$ & 1 & $r$ & 17 & ك & \multirow{2}{*}{ 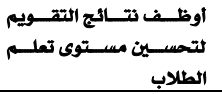 } & \\
\hline & & & & $\because$ & rr.r. & r.\& & v. 1 & rA.1 & $\%$ & & 9 \\
\hline \multirow{2}{*}{$r$} & \multirow{2}{*}{ متدنية } & \multirow{2}{*}{ L.r.e } & \multirow{2}{*}{ r.m } & 1 & 1 & ir & $r$ & in & ك & \multirow{2}{*}{ ملاحظدتهاجات التعلم المراد } & \\
\hline & & & & $r . \varepsilon$ & M.E & YA.T & \$.A & EY.9 & $\%$ & & \\
\hline \multirow{2}{*}{$r$} & \multirow{2}{*}{ متدنية } & \multirow{2}{*}{ 1.ro9 } & \multirow{2}{*}{ r.MT } & . & 1. & 11 & $r$ & in & ك & \multirow{2}{*}{ 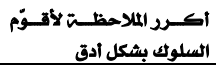 } & \\
\hline & & & & $\because$ & $r r-\Lambda$ & M.Y & $\mathrm{v} .1$ & Er.9 & $\%$ & & \\
\hline \multirow[b]{2}{*}{$\varepsilon$} & \multirow[b]{2}{*}{ متدنية } & \multirow[b]{2}{*}{1.108} & \multirow[b]{2}{*}{ r.Y9 } & . & 1 & iv & $r$ & iv & ك & \multirow{2}{*}{ 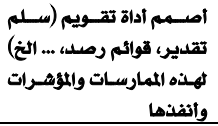 } & \\
\hline & & & & $\because$ & 1E.r. & 8.0 & \&.A & 8.0 & $\%$ & & $\varepsilon$ \\
\hline \multirow[b]{2}{*}{ - } & \multirow[b]{2}{*}{ متدنية } & \multirow[b]{2}{*}{ 1.11\% } & \multirow[b]{2}{*}{ r.19 } & . & 0 & 10 & 0 & iv & ك & \multirow{2}{*}{ 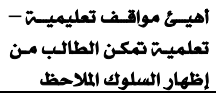 } & \\
\hline & & & & $\because$ & 11.9 & ro.v & 11.4 & $\$ .0$ & $\%$ & & - \\
\hline \multirow{2}{*}{1} & تتشنت & 1.yos & ry & 1 & 1 & ir & $r$ & r. & ك & أحسد الممارسـات والمهمسات & $y$ \\
\hline & متفي & 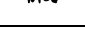 & . & $r . \varepsilon$ & 1E.r & ri. & \$.A & $\varepsilon v .7$ & $\%$ & المطلوبتي، ومؤشرات الأداء & \\
\hline & & & & . & 1 & $\mathbb{E}$ & $r$ & 19 & ك & استخدم الملاحطظات المنظمت & \\
\hline $\mathrm{v}$ & متدنية & $1.1 \mathrm{Tr}$ & r.IV & $\because$ & 1E.r. & rr.r & v. 1 & \&o.Y & $\%$ & 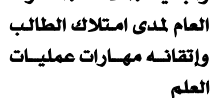 & 9 \\
\hline & & & & . & - & 10 & $r$ & 19 & ك & & \\
\hline$\wedge$ & متدنية & 1.1\% & r.18 & $\because$ & 11.9 & ro.v & v.1 & E.. & $\%$ & أحلل نتائج أداة الملاحظظّ & $\wedge$ \\
\hline & & & & . & 1 & ir & - & 19 & ك & أدوون ملاحطــاتي عـن اداء & \\
\hline p & متدنية & 1.10r & r.Ir & $\because$ & 1E.r. & YA.T & 11.9 & so.r & $\%$ & مناقشت مايطرحة ملف من أفكار & $\mathrm{v}$ \\
\hline & متدذئ & 1..rY & r.ro & & & & & & & & \\
\hline
\end{tabular}

هالمتوسط الحسابي من (..0.0).

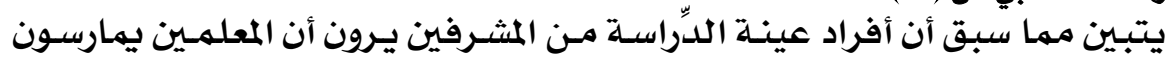

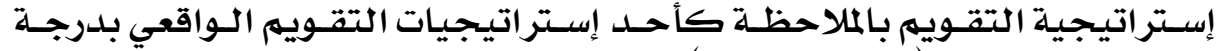

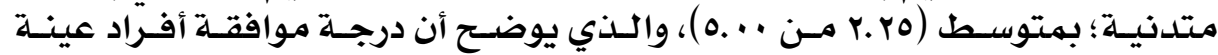

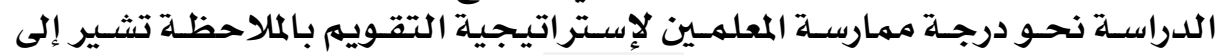




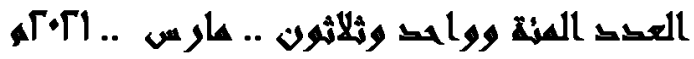

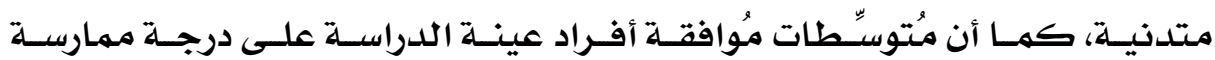

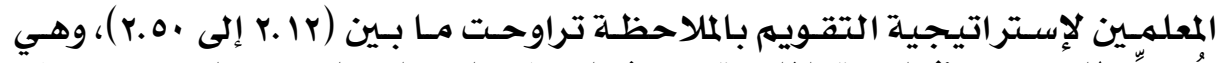

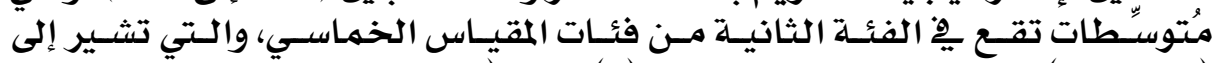

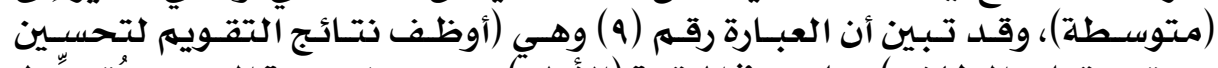

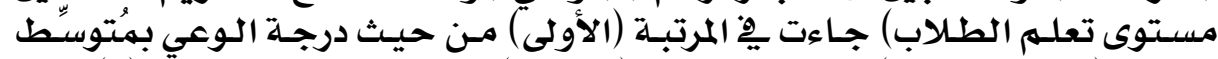

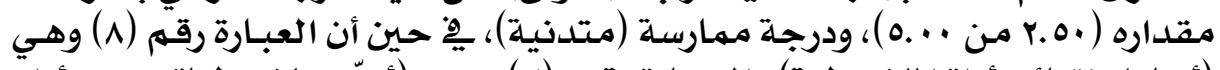

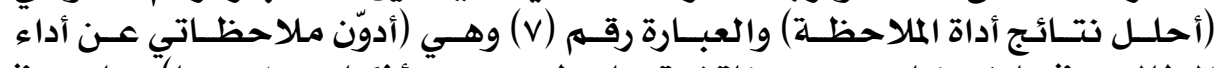

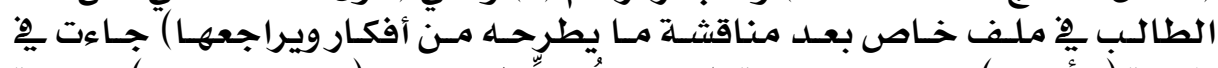

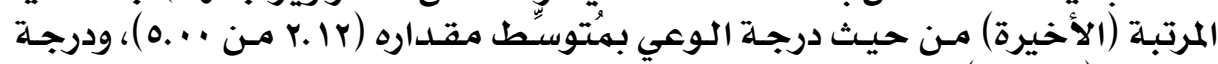

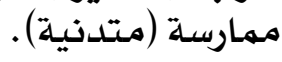

• توبوسيات الدراسة :

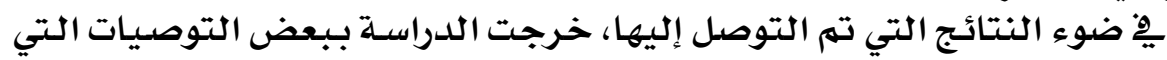

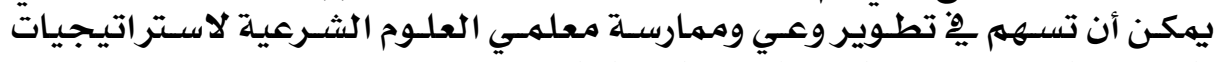

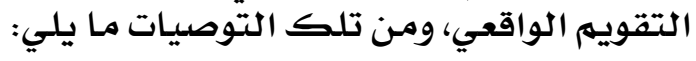

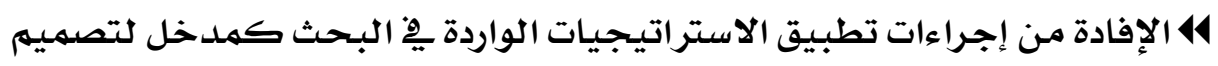

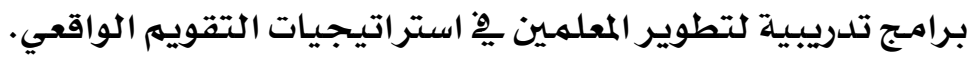

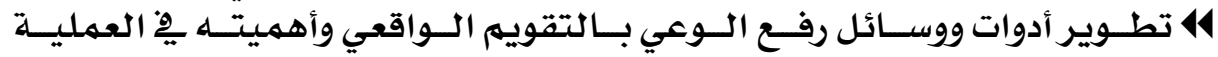

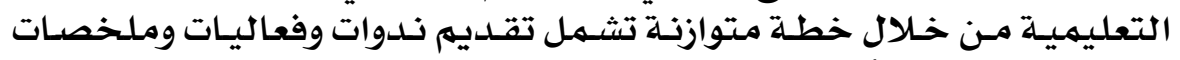

$$
\text { كتب وغيرها من الأدوات. }
$$

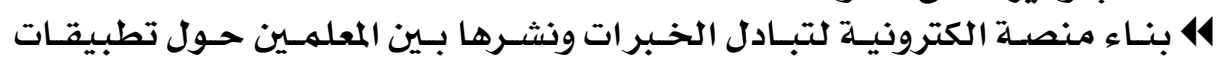

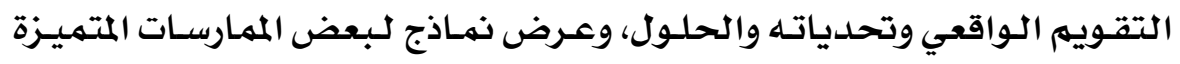
من أداء المعلهـين.

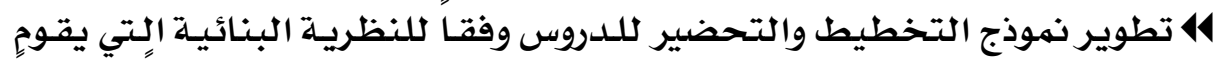

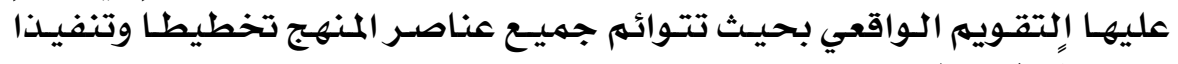
وتقويها وفق نظرية واحدة.

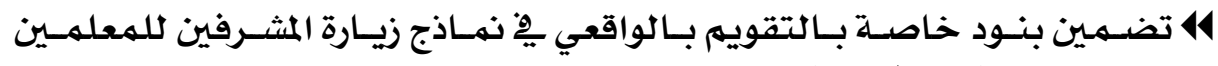

$$
\begin{aligned}
& \text { وتحفيزهم على تطبيقها . }
\end{aligned}
$$

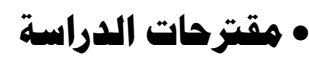

$$
\begin{aligned}
& \text { يقترح الباحث إجـراء الدراسـات التالية: }
\end{aligned}
$$

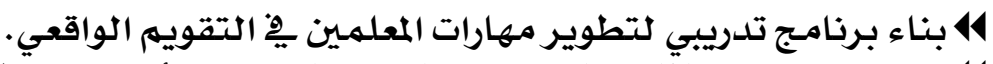

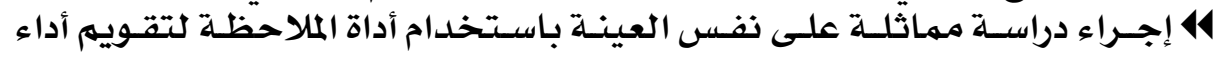

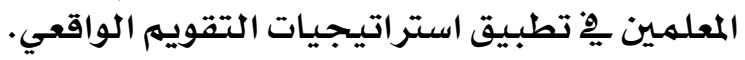

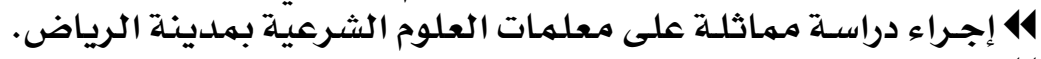

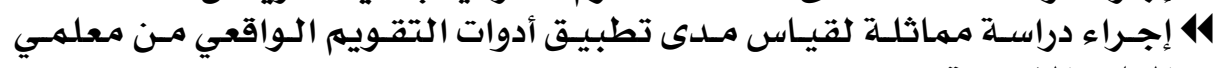
العلوم الشرعية.

\section{9}




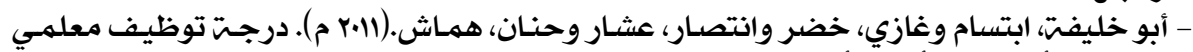

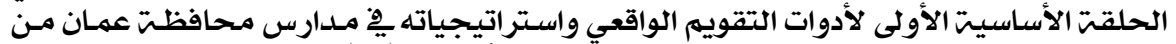

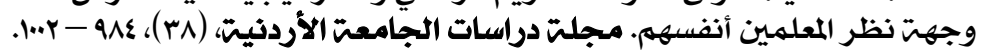

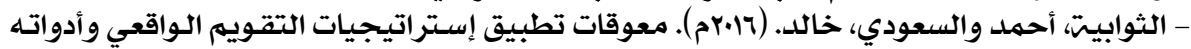

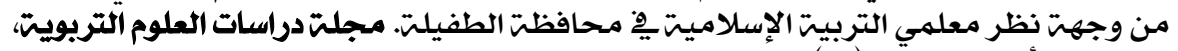

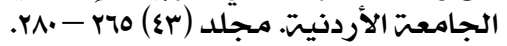

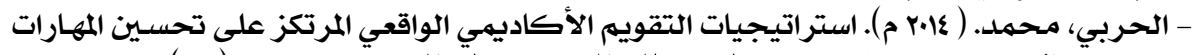

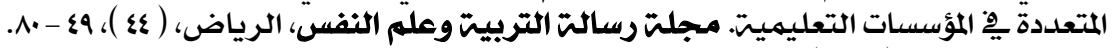

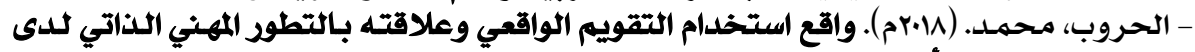

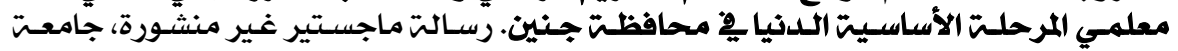

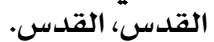

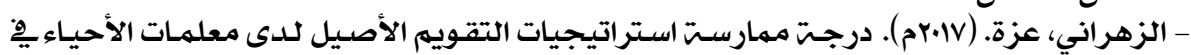

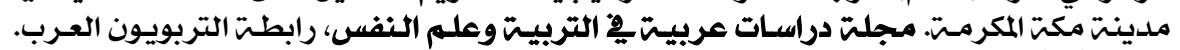

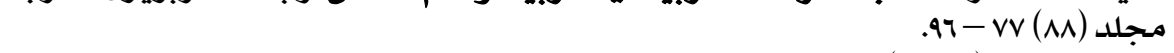

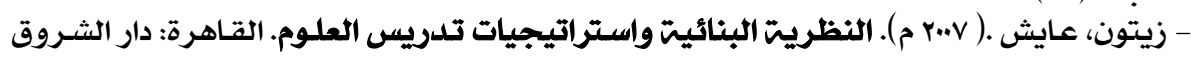
كلنشر.

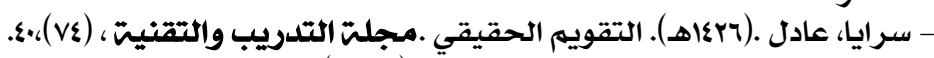

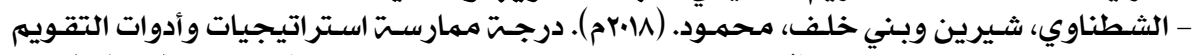

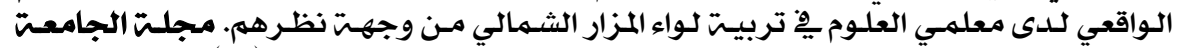

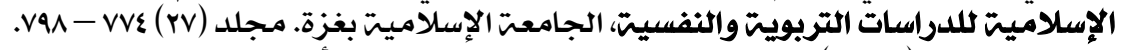

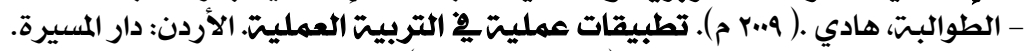

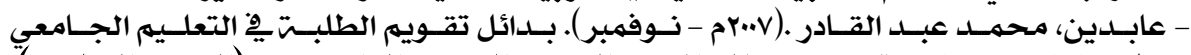

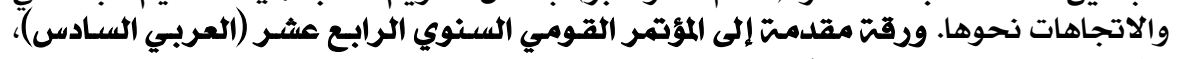

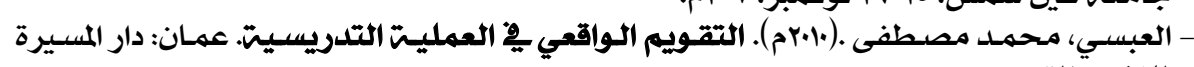

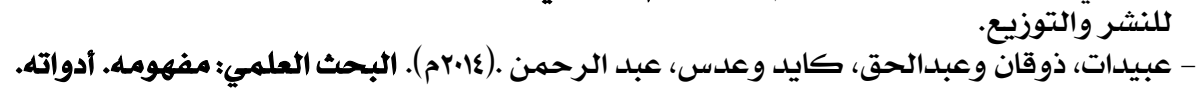

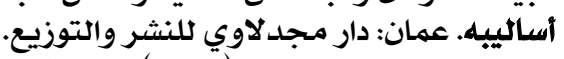

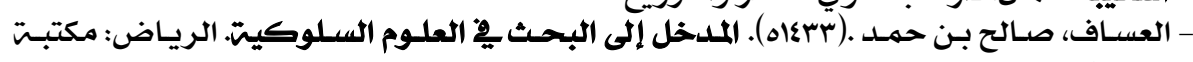
العبيكان.

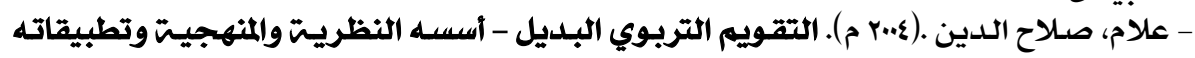
الميداثيتً. القاهرة: دار الفكر العربين.

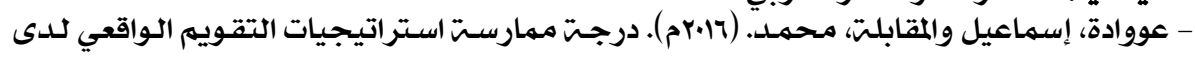

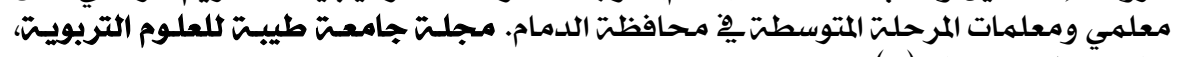

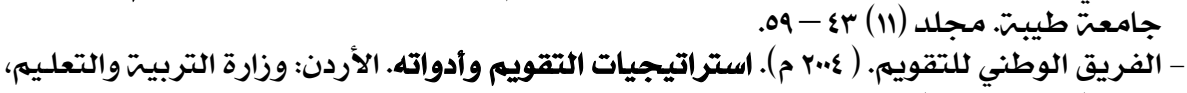

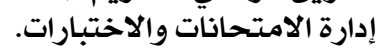

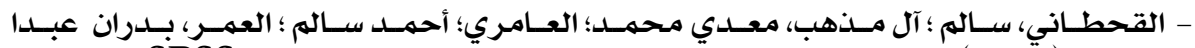

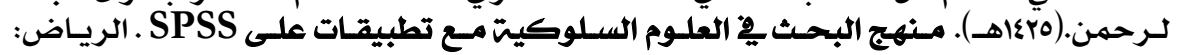

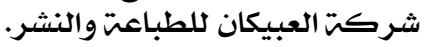

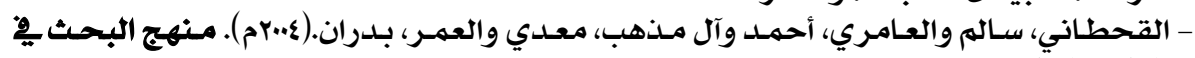

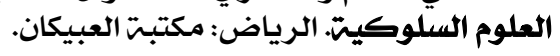




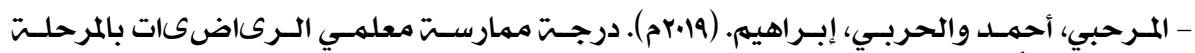

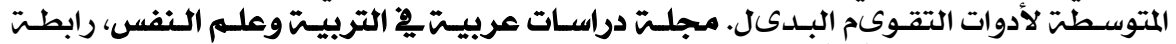

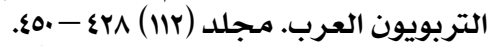

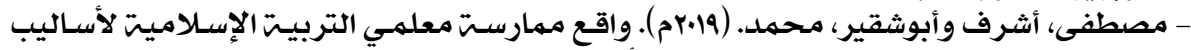

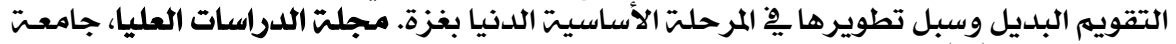

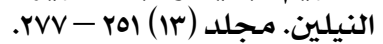

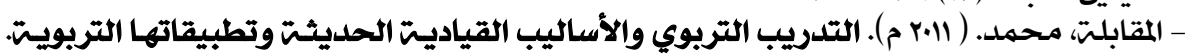

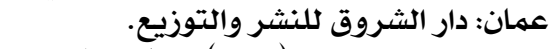

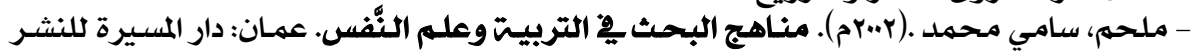
والتوزيع ماحين

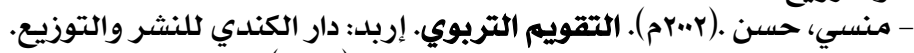

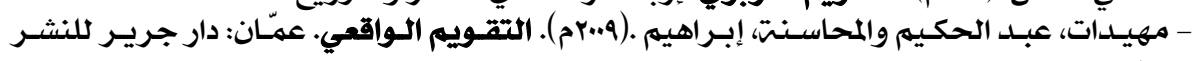

- Alexander, R. (2001). Culture and Pedagogy. Oxford: Blackwell.

- Bullens, D. (2002). Authentic assessment: Change for the future. Full Text from ERIC Available online.

- Gijbels, D, Watering, G, Dochy, F,\& Bossche, P.(2005). Integrating assessment tasks in a problem- based learning environment .Evaluation in Higher Education, 30(1),73-86 .

- Knicker, C. (1997). An Overview of Authentic Assessment. PUPS Newsletters.

- Moss, P. Girard, B\& Hannaford, L. (2006).Validity in educational assessment.Review in Education, 30,109-162. 